This is the author's final, peer-reviewed manuscript as accepted for publication. The publisher-formatted version may be available through the publisher's web site or your institution's library.

\title{
Arabidopsis phospholipase $D \beta 1$ modulates defense responses to bacterial and fungal pathogens
}

Jian Zhao, Shivakumar P. Devaiah, Cunxi Wang, Ruth Welti, Xuemin Wang

\section{How to cite this manuscript}

If you make reference to this version of the manuscript, use the following information:

Zhao, J., Devaiah, S. P., Wang, C., Welti, R., \& Wang, X. (2013). Arabidopsis phospholipase $D \beta 1$ modulates defense responses to bacterial and fungal pathogens. Retrieved from http://krex.ksu.edu

\section{Published Version Information}

Citation: Zhao, J., Devaiah, S. P., Wang, C., Welti, R., \& Wang, X. (2013). Arabidopsis phospholipase $D \beta 1$ modulates defense responses to bacterial and fungal pathogens. New Phytologist, 199(1), 228-240.

Copyright: @ 2013 The Authors. New Phytologist @ 2013 New Phytologist Trust

Digital Object Identifier (DOI): doi:10.1111/nph.12256

Publisher's Link: http://onlinelibrary.wiley.com/doi/10.1111/nph.12256/full

This item was retrieved from the K-State Research Exchange (K-REx), the institutional repository of Kansas State University. K-REx is available at http://krex.ksu.edu 


\section{Running title: PLD $\beta 1$ in defense response}

\section{Title: Arabidopsis phospholipase $\mathrm{D} \beta 1$ modulates defense responses to bacterial and fungal pathogens}

Jian Zhao ${ }^{1,3, *}$, Shivakumar P. Devaiah ${ }^{1}$, Cunxi Wang ${ }^{1}$, Ruth Welti ${ }^{2}$, Xuemin Wang ${ }^{1,4, *}$

${ }^{1}$ Department of Biochemistry and ${ }^{2}$ Division of Biology, Kansas State University, Manhattan, KS, 66506 USA; ${ }^{3}$ College of Plant Science and Technology, National Key Laboratory of Crop Genetic Improvement, Huazhong Agricultural University, Wuhan, China;

${ }^{4}$ Department of Biology, University of Missouri, St. Louis, MO 63121 and Danforth Plant Science Center, St. Louis, MO 63132 USA

\section{*Corresponding author email: swang@danforthcenter.org \& jianzhao@mail.hzau.edu.cn}

\section{Summary:}

- Pathogen infection of higher plants often induces a rapid production of phosphatic acid (PA) and changes in lipid profiles, but the enzymatic basis and the function of the lipid change in pathogen-plant interactions are not well understood.

- Infection of PLD $\beta 1$-deficient plants by Pseudomonas syringae pv. DC3000 resulted in less bacterial growth than in wild-type plants, and the effect was more profound in virulent Pst DC3000 than avirulent Pst DC3000 (avrRpt2) infection. The expression levels of salicylic acid (SA)-inducible genes were higher, but those inducible by jasmonic acid (JA) were lower in PLD $\beta 1$ mutants than in wildtype plants.

- However, $P L D \beta 1$-deficient plants were more susceptible than wild-type plants to the fungus Botrytis cinerea. The PLD $\beta 1$-deficient plants had lower levels of PA, JA and JA-related defense gene expression after $B$. cinerea inoculation.

- PLD $\beta 1$ plays a positive role in pathogen-induced JA production and plant resistance to necrotrophic fungal pathogen $B$. cinerea, but a negative role in the SA-dependent signaling pathway and plant tolerance to the infection of biotrophic Pst DC3000. PLD $\beta 1$ is responsible for the major part of PA 
increased in response to necrotrophic B. cinerea and virulent Pst DC3000 infection, but contributes less to the avirulent Pst DC3000 (avrRpt2)-induced PA production.

Key words: Botrytis cinerea, Pseudomonas syringae, Arabidopsis thaliana, phospholipase D $\beta 1$, pathogeneses, phosphatidic acid, lysophospholipids, lipid signaling.

\begin{abstract}
Abbreviations:
ABA, abscisic acid; HR-hypersensitive response; JA-jasmonic acid; ROS-reactive oxygen species; PA- phosphatidic acid; PLD-phospholipase D; PR-pathogenesis-related protein; SA-salicylic acid; SAR-systemic acquired resistance; ISR-induced systemic resistance; Pst-Pseudomonas syringae pv. tomato; Pst (avrRpt2)-Pseudomonas syringae pv. tomato carrying the avrRpt2 gene; MAMP/PAMPmicrobe or pathogen-associated molecular pattern; PTI-PAMP-triggered immunity; ETI- effectortriggered immunity.
\end{abstract}

\title{
Introduction
}

Plants develop different but inter-related defense systems to battle against invasion of pathogenic microorganisms (Durrant \& Dong, 2004; Abramovitch et al., 2006; Jones \& Dang1, 2006). One system recognizes and responds to molecules common to many classes of microbes, including nonpathogens. This defense response is initiated by recognition of a microbe or pathogen-associated molecular pattern (MAMP/PAMP) by the corresponding pattern recognition receptor, which is typically an integral plasma membrane protein. Another system of defense responds to pathogen virulence effectors, either directly or through their effects on host targets. The effector-triggered defense response involves resistance $(R)$ proteins, usually polymorphic NB-LRR proteins that specifically recognize particular pathogen effectors and launch specific defense response, such as the Arabidopsis R protein RPS2 being recognized as the Pseudomonas syringae effector AvrRpt2 (Glazebrook, 2005; Jones \& Dangl, 2006). The PAMP-triggered immunity (PTI) and effectortriggered immunity (ETI) are closely related and interact in an array of defense responses, such as hypersensitive response, biosynthesis of signaling molecules salicylic acid (SA), jasmonate (JA), and ethylene, and the production of pathogenesis-related proteins and phytoalexins (Durrant \& Dong, 2004; Abramovitch et al., 2006;). Several parallel, yet cross-talking signaling pathways and defense strategies exist, such as SA-dependent systemic acquired resistance in avirulent bacterial infections 
and JA/ethylene-dependent inducible systemic resistance during necrotrophic fungal pathogen infections (Glazebrook 2005; Spoel et al., 2003, Truman et al., 2007). However, the biochemical pathways mediating the cross-talk of different defense responses are not well understood (Glazebrook, 2005; Jones \& Dangl, 2006).

Different aspects of lipid metabolism and signaling play important roles in disease resistance and susceptibility. For example, suppression of $\alpha$-DOX1, a 16- and 18-C fatty acid-dioxygenase, confers enhanced susceptibility to P. syringae (De León et al., 2002). Mutation of DIR1, a putative lipid transfer protein, renders plant deficient in systematic acquired resistance (SAR; Maldonado et al., 2002). Mutation of a plastidic stearoyl acyl-carrier protein desaturase, SSI2, results in an increased SA-mediated SAR (Nandi et al., 2004). Mutation of a phospholipase A (PLA) SOBER1 (Suppressor of AvrBsT Elicited Resistance1) increases the resistance of Arabidopsis ecotype Pi-0 against Pst DC3000 (avrBst). This study also indicates a potential crosstalk between the lysophospholipidproducing PLA and the phosphatidic acid (PA)-producing phospholipase D (PLD) pathways in plant bacterial pathogen interaction (Kirik \& Mudgett, 2009).

PLD, which hydrolyzes membrane phospholipids to generate PA and a free-head group, is involved in cellular processes including reactive oxygen species (ROS) generation (Sang et al., 2001; Park et al., 2004); hormone signaling (Zhang et al., 2004), and disease resistance (den Hartog et al., 2003; Bargmann et al., 2006; Andersson et al., 2006; Yamaguchi et al., 2009). Plant PLD is composed of a family of heterogeneous enzymes with distinguishable catalytic and regulatory properties (Wang et al., 2006). PLD $\beta 1$ from Arabidopsis binds to $\mathrm{Ca}^{2+}$ and phosphatidylinositol-4,5-bisphosphate $\left(\mathrm{PIP}_{2}\right)$ and hydrolyzes phosphatidylethanolamine (PE) preferentially over phosphatidylcholine (PC) (Pappan et al., 1997). The expression of Arabidopsis $P L D \beta 1$ was induced by both bacterial and fungal pathogen infections (Zabela et al., 2002). Tomato LePLD $\beta 1$ was induced by fungal elicitors and RNAi knockdown of $L e P L D \beta 1$ resulted in an increased defense response in response to fungal elicitors (Laxalt et al., 2001; Bargmann et al., 2006). Knockdown of PLDß1 in rice increased resistance against Pyricularia grisea and Xanthomonas oryzae pv oryzae. These results indicate that PLD 1 plays an important role in plant pathogen interactions and also raise further questions. As a phospholipidhydrolyzing enzyme, what effect would PLDß1 have on membrane glycerolipid species without and with pathogen infection? How would a gene-knockout of PLDß1 affect SA- and JA-mediated defense 
response? In this study, we used $P L D \beta 1$-knockout and RNAi-suppressed Arabidopsis plants to investigate the effect of $P L D \beta 1$ on Arabidopsis interaction with the bacterial pathogen Pseudomonas syringae and fungal pathogen Botrytis cinerea. The results indicate that $P L D \beta 1$ plays a role in promoting PA production after pathogen infection. $P L D \beta 1$ plays a negative role in plant resistance to bacterial pathogens but a positive role in plant response to the necrotrophic fungal pathogen $B$. cinerea.

\section{Materials and Methods}

\section{PLDB1 T-DNA-Insertion Knockout Isolation and Complementation}

A T-DNA insertion mutant in PLD $\beta 1$ (At2g42010), designated pld $\beta 1$-1, was identified from the Salk Arabidopsis thaliana (L.) Heynh T-DNA knockout collection (Salk_079133) and seeds were obtained from the ABRC at Ohio State University. A $P L D \beta 1$ homozygous T-DNA insert mutant was isolated by PCR screening using $P L D \beta 1$ gene specific primers, 5'-ATA CCC TCC ACC TGA AAC TAA ACC GCA-3' (forward primer) and 5'-TGTGGCTTATTGTGGAATGCATTACGA-3' (reverse primer) and the T-DNA left border primer, 5'-GCG TGG ACCGCT TGC TGCAACT-3'. The positive T-DNA insertion lines were confirmed by sequencing. The F3 generation shows a homozygous mutation, and deficiency of $P L D \beta 1$ transcripts was confirmed by northern blotting. pld $\beta 1-1$ showed co-segregation with kanamycin resistance in a 3:1 ratio, indicating that the mutant had a single T-DNA insertion. For complementation of the $P L D \beta 1$ knockout mutant, the native $P L D \beta 1$ gene, including its own promoter region, was amplified from $1000 \mathrm{bp}$ upstream of the start codon and $300 \mathrm{bp}$ after the stop codon and then was cloned into the pEC291 vector. The primers for PLD 11 complementation were 5'ATGGCGCGCCAGATTCTCGTCCACTGAGGA-3' (forward) 5'ATGGCGCGCCTAGAGATGGGCTCTGGAGAT-3' (reverse). The construct, pEC291-PLDgy3, was transformed into Agrobacterium tumafaciens strain GV3101 via electroporation. Homozygous pld $\beta 1-1$ plants were transformed (Clough and Bent, 1998), the seeds were collected, and transformants were

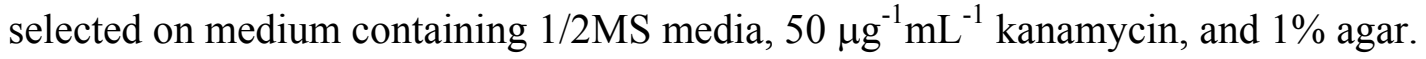

\section{PLDB1 RNAi Construct and Generation of RNAi Suppression Lines}

The sense cDNA exon (492 bp, the last exon plus part of 3'-UTR, from 2784 to 3276 bp in PLD $\beta 1$ mRNA, GeneBank accession number U84568) followed by an intron (101 bp, the last intron, from 29898-29999 bp in Arobidopsis BAC clone T6D20, GeneBank accession number U9292382) was amplified by using PCR with forward primer BIR51: 5'- 
CCCAAGCTTATTTAGAGTGATAATATATC-3' (Hind III site underlined) and reverse primer BIR31: 5'-CCGGAATTCAGATCTATGGATACAG AAT-3' (EcoRI site underlined). Antisense cDNA (492 bp) (the last exon plus 3'-UTR from 2784 to 3276 bp in PLD $\beta 1$ mRNA, GeneBank accession number U84568) was amplified with a forward primer BIR52: 5'CCGGAATTCTGGTCAGGTAAATCCCGCAAAC-3'(EcoR1 site underlined), and the reverse primer BIR32: 5'-CCGCTCGAGATTTAGAGTGATAATATATC-3' (XhoI site underlined). Two PCR products were digested with EcoRI and then ligated into a fragment of $1100 \mathrm{bp}$ containing two inverse cDNA repeats separated by an intron. This fragment was further digested with XhoI and Hand III restriction enzymes, and the resulting fragment was purified and then ligated into pKYLX71-35S ${ }^{2}$ vector in XhoI and Hand III sites. The resulting RNAi vector was confirmed by complete sequencing and transformed into Arabidopsis by the floral dipping method. F1 and F2 seeds were screened using both kanamycin plates and PCR. Two homozygous lines RNAil and RNAi2 were finally obtained with dramatically decreased $P L D \beta 1$ transcripts in leaves as checked by northern blotting.

\section{Pathogen Growth and Inoculation}

Arabidopsis thaliana Col-0, pld $\beta 1$-1, RNAi mutants, and pld $\beta 1-1$ complemented with PLD $\beta 1$ (PLD $\beta 1$ complementation) plants were grown in soil in growth chambers at $23 / 21^{\circ} \mathrm{C}$ and $60-80 \%$ relative humidity under $8 / 16 \mathrm{~h}$ day/night photoperiods $\left(85 \mu \mathrm{mol} \cdot \mathrm{m}^{-2} \cdot \mathrm{s}^{-1}\right)$ for pathogen inoculation, or $16 / 8 \mathrm{~h}$ day/night photoperiods $\left(120 \mu \mathrm{mol} \cdot \mathrm{m}^{-2} \cdot \mathrm{s}^{-1}\right)$ for physiological and genetic analysis. The virulent strain Pseudomonas syringae tomato (Pst) DC3000 and an avirulent strain Pst DC3000 carrying the avirulence gene avrRpt2, Pst DC3000 (avrRpt2) were grown in King's medium B at $28^{\circ} \mathrm{C}$ with appropriate antibiotics $(50 \mathrm{mg} / 1$ of rifampicin for $P s t$ DC3000 and $25 \mathrm{mg} / 1$ of rifampicin plus $50 \mathrm{mg} / \mathrm{L}$ of kanamycin for Pst DC3000 (avrRpt2). Five week-old, soil-grown plants were inoculated with Pst DC3000 and Pst DC3000 (avrRpt2). Bacterial inoculations were performed as previously described (Nandi et al., 2004). The fully expanded leaves of each plant were infiltrated with a suspension containing $10^{7}$ colony-forming units (cfu) per milliliter of Pst DC3000 or Pst DC3000 (avrRpt2). In parallel, plants similarly infiltrated with $10 \mathrm{mM} \mathrm{MgCl}_{2}$ served as the controls. At 0,3 , and 5 days post inoculation, six infected leaves were collected per genotype to measure the growth of the pathogen. Bacterial counts are expressed as colony-forming units per leaf disc. The rate of the lesion area is according to methods described before (Nandi et al., 2004). Each data point represents three replicates, 
with three leaf discs per replicate. Approximately 50 plants of each genotype and more than 300 leaves were treated.

Botrytis cinerea IMI169558 was cultivated on in potato dextrose broth medium at $22^{\circ} \mathrm{C}$ in a growth chamber. Spores were harvested and infections performed as described previously (Nandi et al., 2004). Briefly, a $10 \mu \mathrm{l}$ drop of freshly harvested $B$. cinerea conidial spore suspension $\left(5 \times 10^{7}\right.$ spores $\left./ \mathrm{ml}\right)$ was placed on three leaves of 4 week-old soil-grown plants pricked with a 23-gauge needle. The inoculum was allowed to air dry; plants were covered with a transparent plastic dome and cultivated at $18^{\circ} \mathrm{C}(80$ $-100 \%$ humidity) in a growth chamber programmed for a $14 \mathrm{~h} / 10 \mathrm{~h}$ light-dark cycle. Control plants were inoculated with potato dextrose broth medium alone. The number of leaves showing different levels of lesion was scored at 5 days post inoculation (Nandi et al., 2004). Approximately 50 plants of each genotype and more than 300 leaves were tested.

\section{Extraction and Quantification of SA}

About $0.3 \mathrm{~g}$ fresh leaves were harvested and quickly frozen in liquid $\mathrm{N}_{2}$. SA extraction and determination were performed according to a method described by Nandi et al. (2004). Briefly, frozen samples were ground and extracted once with $3 \mathrm{~mL}$ of $90 \%$ methanol and once with $3 \mathrm{~mL}$ of $100 \%$ methanol. The combined extracts were dried under $\mathrm{N}_{2}$ gas and suspended in $2.5 \mathrm{~mL}$ of $5 \%$ trichloroacetic acid. The samples were acid hydrolyzed by adding $200 \mu \mathrm{L}$ of $\mathrm{HCl}$ and incubating at $95^{\circ} \mathrm{C}$ for $30 \mathrm{~min}$. SA was extracted with $5 \mathrm{~mL}$ of a mixture containing cyclohexane: ethylacetate: isopropanol (50:50:1). The sample was dried under $\mathrm{N}_{2}$ gas and dissolved in $0.5 \mathrm{~mL}$ of the mobile phase (69:27:4 mix of water: methanol: glacial acetic acid). Samples were filtered through a 0.22- $\mu \mathrm{m}$ filter, and 7.5 to $20 \mu \mathrm{L}$ were used for high performance liquid chromatography. Samples were passed over a 4.6 x 250-mm C18 reverse-phase column, and SA was eluted with the mobile phase at a flow rate of $0.8 \mathrm{ml} / \mathrm{min}$. Absorbance of the eluted samples was recorded at $310 \mathrm{~nm}$, and SA concentrations were determined by comparison with SA standards.

\section{RNA Blotting and Immunoblotting}

Five week-old Arabidopsis seedlings that were treated with pathogens or a control solution (water or $10 \mathrm{mM} \mathrm{MgSO}_{4}$ ) were used for gene expression analysis. Whole plants were taken for extraction of RNA (Zhao et al., 2011). Twenty micrograms of RNA was loaded and separated by formaldehyde- 
agrose gel electrophoresis and transferred to a hybridization membrane. ${ }^{32} \mathrm{P}$-labeled DNA probes for pathogenesis-related genes, PR-1 (At2g14610) and PDF1.2 (At5g44420), PLD $\alpha 1$ (At3g15730), PLD 1 (At2g42010), LOX2 (At3g45140), AOS (At5g42650), PR-5(At1g75040), were generated using fulllength cDNA of these genes. The immunoblotting for $P L D \beta 1$ was performed as described previously (Zheng et al., 2002). Proteins were extracted from Arabidopsis leaves and equal amounts of proteins were subjected to $8 \%$ SDS-PAGE, followed by immunoblotting using antibodies against PLD $\beta 1$ and PLD $\alpha 1$. The PLD antibodies were raised against the C-terminal 13-amino acid residue peptide (Zheng et al., 2002).

\section{Real-Time qRT-PCR}

Rosette leaves of indicated age were inoculated with pathogens. Leaves were harvested before infection and mock treatments (time point 0 ) and at the indicated time points after treatment. Total RNA was isolated with the RNeasy plant mini kit (Qiagen, USA). RNA was reverse transcribed using a M-MLV Reverse Transcriptase kit (Life Technologies, Invitrogen) according to the manufacturer's instructions. Primer pairs listed in Supplemental Table 1 (Table S1) online were used for real-time quantification by an $\mathrm{iQ} \AA 5$ multicolor real-time PCR detection system (Bio-Rad). Individual PCR reaction mixtures contained $1 \mu \mathrm{L}$ of diluted cDNA, $10 \mu \mathrm{L}$ of SYBR Green Mastermix (Thermo Scientific), and $250 \mu \mathrm{M}$ of each primer in a final volume of $10 \mu \mathrm{L}$. In all experiments, three biological replicates of each sample and two technical (PCR) replicates were performed. Data were analyzed with $\mathrm{iQ}{ }^{\circledR} 5$ Optical System Software by the comparative $\Delta \Delta \mathrm{CT}$ method. The amount of target genes was normalized over the abundance of the constitutive UBQ5 and Tubulin8 genes. Three biological replicates were analyzed, each consisting of 8 individually infected leaves.

\section{Detection of $\mathrm{O}_{2}$ and Measurement of $\mathrm{H}_{2} \mathrm{O}_{2}$}

After inoculation with bacterial or fungal pathogens for the indicated time, inoculated leaves were detached and infiltrated with nitroblue tetrazolium (NBT) for $2 \mathrm{~h}$. The purple formazan precipitate indicates the location and extent of $\mathrm{O}_{2}{ }^{--}$accumulation. For quantitative measurement of $\mathrm{H}_{2} \mathrm{O}_{2}$, frozen leaves (about $0.2 \mathrm{~g}$ ) were ground to a powder under liquid nitrogen and homogenized with $0.5 \mathrm{ml}$ of $0.2 \mathrm{M} \mathrm{HClO}_{4}$ in a pre-cooled mortar and pestle. The extract was centrifuged at $10,000 \mathrm{~g}$ for $10 \mathrm{~min}$ at $4^{\circ} \mathrm{C}$. The supernatant was collected and neutralized to $\mathrm{pH} 7.0$ to 8.0 with $0.8 \mathrm{M} \mathrm{NH}_{4} \mathrm{OH}$, and briefly centrifuged at $3000 \times \mathrm{g}$ for $5 \mathrm{~min}$ to sediment the insoluble material. After 8-fold dilution, $\mathrm{H}_{2} \mathrm{O}_{2}$ 
concentration was measured with an Amplex Red hydrogen peroxide / peroxidase assay kit (Molecular Probes, Cat. No. A22188, Eugene, OR).

\section{Lipid Profiling and JA Measurement}

The process of lipid extraction, analysis, and quantification was performed as described (Welti et al., 2002). Briefly, both bacterial and fungal inoculated leaves were collected at the sampling time and immersed immediately into $3 \mathrm{~mL} 75^{\circ} \mathrm{C}$ isopropanol with $0.01 \%$ butylated hydroxytoluene (BHT) for $15 \mathrm{~min}$ to inhibit lipolytic activities. This was followed by the addition of $1.5 \mathrm{~mL}$ of chloroform and $0.6 \mathrm{~mL}$ of water. After shaking for $1 \mathrm{~h}$, the extracting solvent was transferred to a clean tube. The tissues were extracted with chloroform-methanol five times with 30-min agitation each time. The extracts were combined and washed with $1 \mathrm{M} \mathrm{KCl}$, followed by another wash with water. The solvent was evaporated with a stream of nitrogen. The remaining plant tissues were dried in an oven at $105^{\circ} \mathrm{C}$ overnight and then weighed for "dry weight", which here refers to the dry weight minus the lipid content. Lipid samples were analyzed with an electrospray ionization triple quadruple mass spectrometer (API 4000, Applied Biosystems). The molecular species of each lipid class were quantified in comparison to two internal standards as previously described (Welti et al., 2002; Devaiah et al., 2006). Five replicates of each treatment for each phenotype were processed and analyzed. The Q-test for discordant data was done on the replicates of the total lipid. Paired values were subjected to $t$-test to determine statistical significance.

JA analysis in B. cinerea-inoculated and control plants was carried out according to the method described previously (Yang et al., 2007; Pan et al., 2008). Leaf samples were harvested at 0, 12 and 24 h post inoculation. About $100 \mathrm{mg}$ of fresh Arabidopsis leaves were sealed in $1.5 \mathrm{~mL}$ snap-cap vials and quickly frozen in liquid $\mathrm{N}_{2}$. The leaf tissues were ground into powder and $500 \mu \mathrm{L}$ of 1propanol $/ \mathrm{H}_{2} \mathrm{O} /$ concentrated $\mathrm{HCl}(2: 1: 0.002, \mathrm{vol} / \mathrm{vol} / \mathrm{vol})$ with internal standards $(50 \mathrm{ng})$ were added, and the samples were agitated for $30 \mathrm{~min}$ at $4^{\circ} \mathrm{C}$. One $\mathrm{ml}$ of $\mathrm{CH}_{2} \mathrm{Cl}_{2}$ was added, and the samples were agitated for another $30 \mathrm{~min}$ and then centrifuged at 13,000g for $5 \mathrm{~min}$. The lower phase $(25 \mu \mathrm{L})$ was

directly infused into a hybrid triple quadrupole/linear ion trap mass spectrometer (ABI 4000 Q-TRAP ${ }^{\circledR}$, Applied Biosystems, Foster City, CA) outfitted with an electrospray (ESI) ion source.

\section{Statistical Analysis}


For most experimental data, including $\mathrm{SA}$ and $\mathrm{H}_{2} \mathrm{O}_{2}$ measurements, three independent experiments were performed; lipid profiling was performed with 5 repeats. The data were analyzed using Students $t$ test. The differences between two tails of data with the error bars represent $95 \%$ confidence limits.

\section{Results}

\section{PLDß1 deletion increased defense response and resistance to Pst DC3000}

To characterize the function of $P L D \beta 1$, we generated RNAi mutants; two lines, RNAil and RNAi2, with $P L D \beta 1$ expression being suppressed to different degrees, were isolated and used in this study (Fig. 1A). RNA blotting indicated that RNAil had about $20-25 \%$ of the wild-type level of PLD $B 1$ transcript, whereas RNAi2 had less than $10 \%$ of the wild-type level of PLD $B 1$ transcript (Fig. 1B). Immunoblotting using $P L D \beta 1$ antibody also confirmed that both RNAil and RNAi2 had a decreased level of PLD $\beta 1$ protein (Fig. 1C). We also isolated one knockout line (pld $\beta 1-1$ ) with the T-DNA inserted in the first exon of $P L D \beta 1,877$ bp downstream of the start codon (Fig. 1D). Elimination of the PLD $\beta 1$ transcript in pld $\beta 1-1$ was confirmed by RNA blotting (Fig. 1D). The three PLD $\beta 1$ mutant lines with varied levels of decreases in $P L D \beta 1$ transcripts were used for further study. Under normal growth conditions, the $P L D \beta 1$-deficient plants displayed no apparent morphological alterations.

We examined the expression of $P L D \beta 1$ in leaves treated with several compounds associated with stresses to gain insights into its function. $P L D \beta 1$ transcript level was increased in leaves with $0.1 \mathrm{mM}$ methyl jasmonate (MeJA), but decreased with $0.1 \mathrm{mM}$ SA or methyl salicylate (MeSA) (Supplemental data Fig. S1A, B). When leaves were treated with $2 \mathrm{mM} \mathrm{H}_{2} \mathrm{O}_{2}$, the expression of PLD $\beta 1$ was suppressed in the early phase $(3 \mathrm{~h})$ but increased later $(20 \mathrm{~h})$. On the other hand, abscisic acid (ABA) treatments induced a transient increase in $P L D \beta 1$ expression at $6 \mathrm{~h}$. When Arabidopsis leaves were inoculated with pathogens, the expression of $P L D \beta 1$ was induced by both virulent (Pst DC3000) and avirulent [Pst DC3000 (avrRpt2)] bacterial pathogens (Fig. 2A, left panel). Fungal pathogen $B$. cinerea infection also markedly induced $P L D \beta 1$ expression (Fig. 2A, right panel). In contrast, $P L D \beta 2$ was not induced by the bacterial or fugal pathogens, When Col-0, RNAil and RNAi2 plants infected with pathogen $B$. cinerea, the $P L D \beta 1$ transcript was increased in Col-0 plants, but only a small amount of $P L D \beta 1$ transcripts were detected in the RNAi lines (Supplemental data Fig. S2). 
To investigate the role of $P L D \beta 1$, in plant response to pathogens, we inoculated $P L D \beta 1$ mutant and wild-type Arabidopsis plants with virulent Pst DC3000 or Pst DC3000 (avrRpt2). Most plants displayed leaf cell collapse in the pathogen-inoculated leaves within $24 \mathrm{~h}$ (Fig. 2B). However, the leaf cell collapse was more evident in the two $R N A i$ lines and pld $\beta 1-1$ plants than in wild-type plants, with PLD $\beta 1$ mutants displaying both earlier development of cell collapse and larger collapse area (Fig. 2B). The accelerated cell collapse in PLD $\beta 1$ mutants occurred with both Pst DC3000 and Pst DC3000 (avrRpt2) (Fig. 2B). Genetic complementation of pld $\beta 1-1$ with native PLD $\beta 1$ restored the mutant's collapses to the wild-type phenotype, suggesting that ablation of $P L D \beta 1$ results in an enhanced resistance to biotrophic pathogen Pst DC3000 (Fig. 2B). No symptoms occurred with control plants treated only with $10 \mathrm{mM} \mathrm{MgSO}_{4}$. A bacterial growth assay showed that $P L D \beta 1$ mutant plants were suppressed in bacterial pathogen growth, and the difference in pathogen growth between pld $\beta 1-1$ and wild-type after virulent Pst DC3000 infection was greater than that after avirulent Pst DC3000 (avrRpt2) infection (Fig. 2C).

Both RNAi mutants and pld $\beta 1-1$ produced higher levels of total SA (free SA and SA glycoside) in response to Pst DC3000 infections (Fig. 3A) and Pst DC3000 (AvrRpt2) infections (Supplemental data Fig. S3). These differences were evident in both inoculated (local) leaves and neighboring (distal) leaves, suggesting a systematic induction of SA production (Fig. 3B). Both quantitative RT-PCR and RNA blotting were used to evaluate defense-related gene expression in treated/non-treated samples. Consistent with the higher level of SA, the SA-inducible pathogenesis-related (PR) gene PRI was upregulated in $P L D \beta 1$ mutants (Fig. 3C; Supplemental data Fig. S4). However, PLD $\beta 1$ mutants displayed a lower level of expression of JA biosynthetic genes allene oxide synthase (AOS), lipoxygenase 2 (LOX2), and JA/ethylene-regulated defensive gene plant defensin 1.2 (PDF1.2) than wild-type (Fig. 3C; Supplemental data Fig. S4).

\section{PLDß1 mutants increased susceptibility to Botrytis cinerea.}

When plants were inoculated with spores of $B$. cinerea, $P L D \beta 1$ mutants displayed accelerated and larger necrotic lesions than did wild-type plants, as indicated by lesion areas measured at day 5 post inoculation (Fig. 4A). In addition, more infected leaves had necrotic lesions with chlorotic halos (Fig. 4B). qRT-PCR and RNA blotting analyses showed that $P L D \beta 1$ mutants had lower levels of expression 
of $L O X 2, A O S$, and PDF1.2, but a higher levels of PR1 expression than did wild-type in response to $B$. cinerea (Fig. 4C; Supplemental data Fig. S5).

We then measured endogenous JA and SA levels in PLD $\beta 1-\mathrm{KO}$, wild-type, and PLD $\beta 1$ complementated plants with or without pathogen inoculation. JA levels in these plants increased greatly $24 \mathrm{~h}$ after $B$. cinerea spore inoculation, but the JA level of pld $\beta 1-1$ was significantly lower than that of wild-type and the $P L D \beta 1$-complemented plants (Fig. 4D). Meanwhile, SA measurement results suggest that $P L D \beta 1-\mathrm{KO}$ and knockdown mutants all had slightly higher levels of total SA after 3 days of spores-inoculation (Fig. 4E), which is consistent with higher PRl expression. These results suggest that abolishing $P L D \beta 1$ impairs fungal pathogen-induced JA production, rendering plants more sensitive to pathogen.

\section{PLD $\beta 1$ mutation increased ROS production in response to pathogens}

We examined if there was a difference between $P L D \beta 1$ mutants and wild-type in cellular ROS accumulation during the defense response. When $\mathrm{O}_{2}{ }^{--}$reacts with nitro blue tetrazolium (NBT), a precipitate of purple formazan forms (Rao et al., 2000) (Fig. 5A). Pathogen-treated leaves of the PLD $\beta 1$-deficient mutants displayed more intense blue staining than those of wild-type. The intensity of blue staining was inversely associated with the level of $P L D \beta 1$ transcript in the two RNAi mutants and pld $\beta 1-1$ (Fig. 5A, B). To verify the association of $P L D \beta 1$ deficiency with ROS production, we measured $\mathrm{H}_{2} \mathrm{O}_{2}$ levels in infected leaves. $P L D \beta 1$ mutants generated more $\mathrm{H}_{2} \mathrm{O}_{2}$ than wild-type plants in response to both bacterial pathogens, Pst DC3000 and Pst DC3000 (AvrRpt2), and fungal (B. cinerea) pathogen infections (Fig. 5C, D, Supplemental data Fig.S6). The enhanced ROS production in $P L D \beta 1$-deficient plants was correlated with a stronger defensive response and more severe necrotic responses than observed in wild-type plants.

\section{PLDß1 ablation decreased virulent pathogen-induced production of phosphatidic acid.}

To determine whether ablation of $P L D \beta 1$ changed the cellular level of PA, we quantitatively profiled phospholipids and galactolipids in Col-0, pld $\beta 1-1$, and complementation plants with or without pathogen treatments. There was no difference in PA levels between Col-0, pld $\beta 1-1$, and complementation plants without treatment. Inoculation with $B$. cinerea spores induced significant increases in PA in all three genotypes, but the PA increase in pld $\beta 1-1$ was significantly lower than that 
in Col-0 and complementation plants (Fig. 6). Levels of the major PA species, 34:2-, 34:3-, 36:4-, 36:5-, and 36:6-PA, in pld $\beta 1-1$ were significantly lower than those in wild-type plants after the fungal pathogen treatment (Supplemental data Fig. S7). .

The PA increase was also observed when the plants were treated with virulent pathogen Pst DC3000 (Fig. 6). Pst DC3000 infection significantly increased PA production $24 \mathrm{~h}$ post inoculation, but pld $\beta 1$ 1 had lower PA levels than wild-type and PLD $\beta 1$-complemented plants after Pst DC3000 infection (Fig. 6). The major PA species such as 34:2-, 34:3-, 36:4-, 36:5- and 36:6-PA were significantly lower in pld $\beta 1-1$ than wild-type and $P L D \beta 1$-complementation plants treated with virulent bacterial pathogens (Supplemental data Fig. S7). Inoculation with avirulent pathogen Pst DC3000 (avrRpt2) induced more PA production than did Pst DC3000 and B. cinerea infections, but pld $\beta 1-1$ did not show much difference from wild-type or PLD $\beta 1$-complemented plants in PA levels (Fig. 6). These results suggest that $P L D \beta 1$ plays a different role in virulent and virulent bacterial pathogen-induced PAPA production: whereas it contributes significantly to the virulent pathogen-induced PA production, but less to the avirulent pathogen-induced PA under this assay condition.

The level of total PC, PE, PI, PG, and DGDG, were comparable in wild-type and pld $\beta 1-1$ with or without pathogen infection (Fig. 6). However, infections resulted in different changes between wildtype and pld $\beta 1-1$ when lipid molecular species were analyzed (Supplemental data Fig. S8). Treatment with $B$. cinerea tended to raise levels of $34: 3,36: 5,36: 6$ PCs and 34:3 PE, and treatment with Pst DC3000 resulted in higher levels of 36:5 and 36:6 PC in the PLD 1 mutant (Supplemental data Fig S8). These higher levels of $\mathrm{PC}$ and $\mathrm{PE}$ molecules in $P L D \beta 1$ mutants versus wild-type plants after pathogen treatments are associated with the lower levels of PA production in PLD $\beta 1$ than wild-type. These data might suggest that PC and PE are potential in vivo substrates of PLD $\beta 1$.

\section{PLDß1-KO had elevated lysophospholipid levels in virulent pathogen-infected leaves.}

In contrast to the lesser increase in PA in pld 1 1-1, higher levels of total LPC, LPE, and LPG levels were found $\mathrm{r}$ in pld $\beta 1-1$ than in wild-type and complemented plants after $B$. cinerea infections, whereas without infection, $p l d \beta 1-1$ and wild-type displayed no significant difference (Fig. 7, top panel). After virulent Pst DC3000 infection, pld $\beta 1-1$ plants also had higher levels of LPE and LPG that wild-type (Fig. 7, middle panel). However, after the avirulent pathogen Pst DC3000 (avrRpt2) 
infection, only LPG was significantly higher in $p l d \beta 1-1$ than wild-type, and the difference in LPG between wild-type and pld $\beta 1-1$ was also smaller than that of virulent Pst DC3000-infected plants (Fig. 7, bottom panel). In addition, the avirulent Pst DC3000 (avrRpt2) infection showed an increase in lysophospholipid levels in wild-type, pld $\beta 1-1$, and complementation plants (Fig. 7, bottom panel). However, no such increase was observed in wild-type and complementation plants after virulent Pst DC3000 or B. cinerea infections (Fig. 7, top and middle panels).

The major LPC and LPE species were 18:3-, 18:2-, and 16:0- species (Supplemental data Fig. S9A, B), whereas 18:3-, 16:1-, and 16:0- were the major LPG species (Fig. 7D). At $24 \mathrm{~h}$ post inoculation with Pst DC3000, both 18:3-LPC and 18:2-LPC were higher in pld $\beta 1$-1 than in wild-type and complemented plants (Supplemental data Fig. S9C). In the pld $\beta 1-1$ plants, the formation of 16:1-LPG after pathogen inoculation was particularly apparent (Supplemental data Fig. S9C).

\section{Discussion}

Our results show that PLD $\beta 1$ is a negative regulator of the SA-dependent resistance to Pseudomonas syringae, Pst DC3000, but a positive regulator of the JA-dependent pathway and resistance to $B$. cinerea. The negative role of PLD $\beta 1$ was indicated by the increased production of SA, SA-inducible genes, and decreased damage of virulent bacterial infection. The positive effect of PLD $\beta 1$ on the JAdependent signaling pathway was indicated by the decreased expression in JA-biosynthetic and responsive genes, decreased JA production, and increased damage in response to $B$. cinerea inoculation. $B$. cinerea inoculation has been reported to induce a substantial increase in JA (Truman et al., 2007, Yang et al., 2007). On the other hand, the expression of $P L D \beta 1$ is induced by JA and also by wounding (Wang et al 2001). Of the four PLDs ( $\alpha 1, \gamma 1, \gamma 2$, and $\beta 1$ ) examined, the greatest increase for $P L D \beta 1$ mRNA occurred 30 min after wounding, whereas that for $P L D \gamma 1$ and $\gamma 2$ transcripts was at 60 min after wounding and for PLD $\alpha$ mRNA was at 3 to $6 \mathrm{hr}$ after wounding (Wang et al., 2001). However, the wounding-induced JA production in Arabidopsis peaked one hour after wounding (Wang et al., 2001). These results could mean that PLD $\beta 1$ is involved in pathogen- and woundinginduced JA production. The SA-dependent and JA/ethylene-dependent signaling pathways in Arabidopsis contribute to resistance against distinct microbial pathogens (Durrant \& Dong, 2004; Spoel et al., 2003; Truman et al., 2007). Yet, a close interplay exists between the two pathways. For example, NPR1 (NON-EXPRESSOR OF PR GENES1) mutant that is impaired in SA signaling 
produces higher level of JA and shows an increased susceptibility to pathogens (Spoel et al., 2003). The effects of PLD $\beta 1$ on plant pathogen interactions indicate that PLD $\beta 1$ and associated lipid changes are involved in the SA-dependent and JA/ethylene-dependent plant defenses against bacterial and fungal pathogens.

Treatment of plants with $P$. syringae with or without AvrRpm1 or AvrRpt2, rhizobium, fungal pathogen, or elicitors all have been reported to induce PA production (van der Luit et al., 2000; de Jong et al., 2004; Bargmann et al., 2006; Andersson et al., 2006). However, the specific PLD that is responsible for the pathogen-induced PA production was unknown. The current study shows that knockout of $P L D \beta 1$ decreases the PA production induced by $B$. cinerea and virulent Pst DC3000 infection, but the loss of $P L D \beta 1$ had no major impact on the avirulent pathogen Pst DC3000 (avrRpt2)-induced PA production. The results indicate that $P L D \beta 1$ is responsible for a major portion of the PA generated during virulent bacterial and fungal pathogen attack, but it contributed less to the avirulent pathogen-induced PA production under the present assay condition. It is possible that other PLDs, such as PLD $\alpha 1$ and PLD $\delta$, besides PLD $\beta 1$, are activated in the plant-avirulent DC3000 (avrRpt2) interaction, thus masking the difference in PA production between pld $\beta 1-1$ and wild-type plants. Specifically, PLD $\delta$ has been shown to be responsible for most $\mathrm{H}_{2} \mathrm{O}_{2}$-induced PA production (Zhang et al., 2003). The avirulent infection induced more $\mathrm{H}_{2} \mathrm{O}_{2}$ production than virulent infection (Fig. S6 vs Fig. 5D), which may result in increased PLD $\delta$ activity under the DC3000 (avrRpt2) infection. Thus, these data indicate that other PLDs, besides PLD $\beta 1$, are involved in the pathogeninduced PA production, and under avirulent infection the other PLDs contribute more, thus overwhelming the effect of $P L D \beta 1$ abrogation. However, pldB1-1 still displayed increased resistance to avirulent DC3000 (avrRpt2) infection even though difference in PA levels was undetected between pld $\beta 1-1$ and wild-type plants. One of the explanations for this is that the PA produced by other PLDs may play a less (or a different) role in heightening disease sensitivity, than does PLD $\beta 1$-derived PA. Different PLDs and their derived PA have been shown to play distinguishable roles in plant response to different stresses (Zhang et al., 2003; 2009).

Unlike the attenuated increase in PA, the levels of lysophospholipids, LPC, LPE, and LPG in the pathogen-infected $P L D \beta 1$-deficient plants were higher than those of wild-type plants. This inverse relationship between PA and lysophospholipids in bacterial infection was also observed with another 
mutant, SOBER1, which affected Arabidopsis-Pst DC3000 (avrBst) interactions (Kirik \& Mudgett, 2009). SOBER1 is a $\mathrm{PLA}_{2}$ that negatively regulates pathogen-induced PA accumulation. Both SOBER1 and PLD $\beta 1$ are negative regulators in Pst DC3000 (AvrBst) and virulent Pst DC3000 defense, respectively. The data could mean a cross-talk between PLD and PLA pathways in plantpathogen interaction. Such an interaction has been also proposed to occur in plant response to wounding and senescence (Ryu \& Wang, 1996; Ryu et al., 1997). LPE was reported to inhibit PLD $\alpha$ to decrease PA production and delay senescence (Ryu et al., 1997). It is conceivable that lysophospholipids may inhibit PLD $\beta$ and other PLDs to suppress PA production (Kirik \& Mudgett, 2009). The present findings suggest that the ablation of PLD $\beta 1$ results in an increase in PLA activity. It would be of interest in future studies to determine how PLD $\beta$ and its derived PA suppress PLA and the production of lysolipids.

PLD and PA are both involved in ROS production and response (Sang et al., 2001; Park et al., 2004; Andersson et al., 2006). PLD $\alpha 1$-derived PA has been shown to directly interact with NADPH oxidase on the plasma membrane and promote ROS production (Zhang et al., 2009). However, the present study shows that PLD $\beta 1$-deficient plants produced a lower level of PA, yet a higher level of ROS in response to virulent bacterial and fungal pathogen. The same trend has also been observed in PLD $\beta 1$ deficient rice and tomato (Bargmann et al., 2006; Yamaguchi et al., 2009). These results suggest that PLD $\beta 1$ and its derived PA are unlikely to promote ROS production, and instead they may play a role in mediating ROS response, similar to that of PLD $\delta$ where ablation of PLD $\delta$ rendered plants more sensitive to ROS-promoted cell death (Zhang et al., 2003). PLD $\beta 1$ mutants showed an increased HR phenotype in response to avirulent or virulent Pst DC3000 infections. The effects may result from increased ROS damage in $P L D \beta 1$ mutants compared to wild-type plants. The increased level of ROS in PLD $\beta 1$-deficient mutants may increase SA biosynthesis, which in turn enhances ROS level because SA inhibits catalase activity (Durner \& Klessig, 1995; Martinez et al., 2000). Rapid biosynthesis of SA is important for plant to establish systematic resistance to Pst DC3000 (Durrant \& Dong, 2004).

\section{Conclusion}

The present data indicate PLD $\beta 1$ plays a positive role in pathogen-induced PA production, JA accumulation, JA-dependent defense gene expression, and plant resistance to pathogenesis of necrotrophic fungal pathogen $B$. cinerea. On the other hand, PLD $\beta 1$ suppresses SA-dependent 
signaling pathway and defense gene expression, thus, negatively affecting plant resistance to the infection of biotrophic Pst DC3000. In addition, the results suggest that PLD $\beta 1$ may suppress the production of lysolipids, implying a cross-talk between the PLD $\beta 1$ - and PLA-mediated signaling in plant response to bacterial and fungal pathogens. Further study is needed to determine whether the inverse relationship between PA and lysophospholipid production may underlie a chemical mechanism that modulates plant-pathogen interactions.

\section{Acknowledgements}

We thank Mary Roth for lipid analysis and Maoyin Li for hormone analysis. The work was supported by grants from National Science Foundation (IOS-0818740; MCB-0922879) and the US Department of Agriculture to XW. Equipment acquisition and method development at the Kansas Lipidomics Research Center were funded by National Science Foundation (EPS 0236913, MCB 0455318 and 0920663, DBI 0521587), Kansas Technology Enterprise Corporation, K-IDeA Networks of Biomedical Research Excellence (INBRE) of National Institute of Health (P20RR16475), and Kansas State University.

\section{References}

Abramovitch RB, Anderson JC, Martin GB. 2006. Bacterial elicitation and evasion of plant innate immunity. Nature Review of Molecular Cell Biology 7:601-611

Andersson MX, Kourtchenko O, Dangl JL, Mackey D, Ellerström M. 2006. Phospholipasedependent signalling during the AvrRpm1- and AvrRpt2-induced disease resistance responses in Arabidopsis thaliana. Plant Journal 47:947-959

Bargmann BO, Laxalt AM, Riet BT, Schouten E, van Leeuwen W, Dekker HL, de Koster CG, Haring MA, Munnik T. 2006. LePLDbeta1 activation and relocalization in suspension-cultured tomato cells treated with xylanase. Plant Journal 45:358-368

Clough SJ, Bent AF. 1998. Floral dip: a simplified method for Agrobacterium-mediated transformation of Arabidopsis thaliana. Plant Journal 16:735-743

de Jong CF, Laxalt AM, Bargmann BO, de Wit PJ, Joosten MH, Munnik T. 2004. Phosphatidic acid accumulation is an early response in the Cf-4/Avr4 interaction. Plant Journal 39: 1-12 
De León IP, Sanz A, Hamberg M, Castresana C. 2002. Involvement of the Arabidopsis alphaDOX1 fatty acid dioxygenase in protection against oxidative stress and cell death. Plant Journal 29: $61-62$

den Hartog M, Verhoef N, Munnik T. 2003. Nod factor and elicitors activate different phospholipid signaling pathways in suspension-cultured alfalfa cells. Plant Physiology 132:311-317

Devaiah SP, Roth MR, Baughman E, Li M, Tamura P, Jeannotte R, Welti R, Wang X. 2006. Quantitative profiling of polar glycerolipid species and the role of phospholipase $\mathrm{D}_{\alpha} 1$ in defining the lipid species in Arabidopsis tissues. Phytochemistry 67: 1907-1924

Durner J, Klessig DF. 1995. Inhibition of ascorbate peroxidase by salicylic acid and 2,6dichloroisonicotinic acid, two inducers of plant defense responses. Proceedings of the National Academy of Sciences, USA 92:11312-11316

Durrant WE, Dong X. 2004. Systemic acquired resistance. Annual Review of Phytopathology 42: 185-209

Jones JDG, Dangl JL. 2006. The plant immune system. Nature 444: 323-329

Kirik A, Mudgett MB. 2009. SOBER1 phospholipase activity suppresses phosphatidic acid accumulation and plant immunity in response to bacterial effector AvrBsT. Proceedings of the National Academy of Sciences, USA 106: 20532-20537

Laxalt AM, ter Riet B, Verdonk JC, Parigi L, Tameling WI, Vossen J, Haring M, Musgrave A, Munnik T. 2001. Characterization of five tomato phospholipase D cDNAs: rapid and specific expression of LePLDbeta1 on elicitation with xylanase. Plant Journal 26:237-247

Maldonado AM, Doerner P, Dixon RA, Lamb CJ, Cameron RK. 2002. A putative lipid transfer protein involved in systemic resistance signaling in Arabidopsis. Nature 419: 399-403

Martinez C, Baccou JC, Bresson E, Baissac Y, Daniel JF, Jalloul A, Montillet JL, Geiger JP, Assigbetsé K, Nicole M. 2000. Salicylic acid mediated by the oxidative burst is a key molecule in local and systemic responses of cotton challenged by an avirulent race of Xanthomonas campestris pv malvacearum. Plant Physiology 122: 757-766

Nandi A, Welti R, Shah J. 2004. The Arabidopsis thaliana dihydroxyacetone phosphate reductase gene SUPPRESSSOR OF FATTY ACID DESATURASE DEFICIENCY1 is required for glycerolipid metabolism and for the activation of systemic acquired resistance. Plant Cell 16:465-477 
Pan X, Welti R, Wang X. 2008. Simultaneous quantification of major phytohormones and related compounds in crude plant extracts by liquid chromatography-electrospray tandem mass spectrometry. Phytochemistry 69: 1773-1781

Pappan K, Qin W, Dyer JH, Zheng S, Wang X. 1997. Molecular cloning and functional analysis of polyphospho inositide-dependent phospholipase D, PLDß, from Arabidopsis. Journal of Biological Chemistry 272: 7055-7061

Park J, Gu Y, Lee Y, Yang Z, Lee Y. 2004. Phosphatidic acid induces leaf cell death in Arabidopsis by activating the Rho-related small G protein GTPase-mediated pathway of reactive oxygen species generation. Plant Physiology 134: 129-136

Rao MV, Lee H, Creelman RA, Mullet JE, Davis KR. 2000. Jasmonic acid signaling modulates ozone-induced hypersensitive cell death. Plant Cell 12:1633-1646

Ryu SB, Karlsson BH, Ozgen M, Palta JP. 1997. Inhibition of phospholipase D by lysophosphatidylethanolamine, a lipid-derived senescence retardant. Proceedings of the National Academy of Sciences, USA 94:12717-12721

Ryu SB, Wang X. 1996. Activation of phospholipase D and the possible mechanism of activation in wound-induced lipid hydrolysis in castor bean leaves. Biochim Biophys Acta 1303:243-250

Sang Y, Cui D, Wang X. 2001. Phospholipase D- and phosphatidic acid-mediated generation of superoxide in Arabidopsis. Plant Physiology 126: 1449-1458

Spoel SH, Koornneef A, Claessens SM, Korzelius JP, Van Pelt JA, Mueller MJ, Buchala AJ, Métraux JP, Brown R, Kazan K, Van Loon LC, Dong X, Pieterse CM. 2003. NPR1 modulates cross-talk between salicylate- and jasmonate-dependent defense pathways through a novel function in the cytosol. Plant Cell 15: 760-770

Truman W, Bennett MH, Kubigsteltig I, Turnbull C, Grant M. 2007. Arabidopsis systemic immunity uses conserved defense signaling pathways and is mediated by jasmonates. Proceedings of the National Academy of Sciences USA 104: 1075 - 1080

Van der Luit A, Piatti T, van Doorn A, Musgrave A, Felix G, Boller T, Munnik T. 2000. Elicitation of suspension-cultured tomato cells triggers the formation of phosphatidic acid and diacylglycerol pyrophosphate. Plant Physiology 123:1507-1515

Wang C, Zien CA, Afitlhile M, Welti R, Hildebrand DF, Wang X. 2001. Involvement of phospholipase D in wound-induced accumulation of jasmonic acid in Arabidopsis. Plant Cell 12: 2237-2246 
Wang X, Devaiah SP, Zhang W, Welti R. 2006. Signaling functions of phosphatidic acid. Progress in Lipid Research 45: 250-278

Welti R, Li W, Li M, Sang Y, Biesiada H, Zhou HE, Rajashekar CB, Williams TD, Wang X. 2002.Profiling membrane lipids in plant stress responses: role of phospholipase D alpha in freezinginduced lipid changes in Arabidopsis. Journal of Biological Chemistry 277: 31994-32002

Yamaguchi T, Kuroda M, Yamakawa H, Ashizawa T, Hirayae K, Kurimoto L, Shinya T, Shibuya N. 2009. Suppression of a phospholipase D gene, OsPLDbeta1, activates defense responses and increases disease resistance in rice. Plant Physiology 150:308-319

Yang W, Devaiah SP, Pan X, Isaac G, Welti R, Wang X. 2007. AtPLAI is an acyl hydrolase involved in basal jasmonic acid production and Arabidopsis resistance to Botrytis cinerea. Journal of Biological Chemistry 282:18116-18128

Zabela MD, Fernandez-Delmond I, Niittyla T, Sanchez P, Grant M. 2002. Differential expression of genes encoding Arabidopsis phospholipases after challenge with virulent or avirulent Pseudomonas isolates. Molecular Plant Microbe Interaction 15: 808-816

Zhang W, Qin C, Zhao J, Wang X. 2004. Phospholipase D $\alpha 1$-derived phosphatidic acid interacts with $\mathrm{ABI} 1$ phosphatase $2 \mathrm{C}$ and regulates abscisic acid signaling. Proceedings of the National Academy of Sciences USA 101: 9508-9513

Zhang W, Wang C, Qin C, Wood T, Olafsdottir G, Welti R, Wang X. 2003. The oleate-stimulated phospholipase D, PLDdelta, and phosphatidic acid decrease $\mathrm{H}_{2} \mathrm{O}_{2}$-induced cell death in Arabidopsis. Plant Cell 15:2285-2295

Zhang Y, Zhu H, Zhang Q, Li M, Yan M, Wang R, Wang L, Welti R, Zhang W, Wang X. 2009. Phospholipase D $\alpha 1$ and phosphatidic acid regulate NADPH oxidase activity and production of reactive oxygen species in ABA-mediated stomatal closure in Arabidopsis. Plant Cell 21:2357-77

Zhao J, Wang C, Bedair M, Welti R, Sumner LW, Baxter I, Xuemin Wang X. 2011. Suppression of phospholipase D $\gamma$ s confers increased aluminum resistance in Arabidopsis thaliana PLoS ONE 6: e28086. doi:10.1371

Zheng L, Krishnamoorthi R, Zolkiewski M, Wang X. 2000. Distinct calcium binding properties of novel C2 domains of plant phospholipase D $\alpha$ and $\beta$. Journal of Biological Chemistry 275: 1970019706 
Zheng L, Shan J, Krishnamoorthi R, Wang X. 2002. Activation of plant phospholipase D by phosphatidylinositol 4,5-bisphosphate: characterization of binding site and mode of action. Biochemistry 41: 4546-4553

\section{Supporting Information}

\section{Fig. S1-S9:}

\section{Fig. S1. PLDß1 Expression Pattern}

(A) Expression of PLDB1 in response to various stresses. Arabidopsis Col-0 ecotype (3 week old) leaves were detached and floated on water without (Control) or with indicated chemicals: $2 \mathrm{mM} \mathrm{H}_{2} \mathrm{O}_{2}$, $0.1 \mathrm{mM}$ salicylic acid (SA), $0.1 \mathrm{mM}$ methyl salicylic acid (MeSA), $0.1 \mathrm{mM}$ abscisic acid (ABA), or $0.1 \mathrm{mM}$ methyl jasmonate (MeJA) in a growth chamber at $22{ }^{\circ} \mathrm{C}$. Leaves were collected at the indicated times for RNA extraction and northern blotting. All sample RNAs from different treatments at different time points were equally loaded as indicated by ethidium bromide-stained 28S RNA. One representative photo from three repeats was shown.

(B) Quantification of $P L D \beta 1$ in response to stresses. Data were average $\pm \mathrm{SD}$ using software to measure band intensity compared with control.

Fig. S2. $P L D \beta 1$ expression in Arabidopsis leaves induced by Botrytis cinerea infection in Col-0 and $P L D \beta 1$ mutants. Equal amounts of RNAs from leaves were loaded as indicated by ethidium bromidestained 28S RNA, one representative 28S RNA from three experiments was shown here.

Fig. S3. Salicylic acid in pathogen-inoculated Arabidopsis leaves. Samples were harvested after inoculation of Pst DC3000 (avrRpt2) (2 x $107 \mathrm{cfu} / \mathrm{mL}$.. Total SA (free SA + SA glycosides) in the wild-type, pld $\beta$ 1-1, RNAi1, RNAi2, and pld $\beta 1-1$ complementation plants were determined by HPLC. Data are presented as means $\pm \mathrm{SD}(\mathrm{n}=3)$. Different letters indicate sample groups with significant differences $(p<0.05)$ from each other.

Fig. S4. Bacterial infection induced defense gene expression in wild-type and pld $\beta 1-1$ Arabidopsis leaves. Quantification of expression levels of defense-related genes in Pst DC3000 (A), and Pst DC3000 (avrRpt2) (B) ( all bacterial suspension are $2 \times 10^{7} \mathrm{cfu} / \mathrm{mL}$ ) inoculated plants with altered 
PLD $\beta 1$ expression in Fig. 3C. The band intensity was measured by densitometry from three separate experiments. Data are presented as means $\pm \mathrm{SD}(\mathrm{n}=3)$.

Fig. S5. Defense-related gene expression induced by Botrytis cinerea infection in Arabidopsis Col-0 and $P L D \beta 1$ mutants. Equal amounts of RNAs from leaves were loaded. RNAs from leaf samples were equally loaded as indicated by ethidium bromide-stained 28S RNA, one representative 28S RNA from three experiments was shown here.

Fig. S6. $\mathrm{H}_{2} \mathrm{O}_{2}$ quantification in Pst DC3000 (avrRpt2)-infected Arabidopsis leaves. The wild-type (Col-0), pld $\beta 1-1$, and RNAi2 plants were inoculated with Pst DC3000 ( $\left.2 \times 10^{7} \mathrm{cfu} / \mathrm{ml}\right)$ and leaves were collected at different time post inoculation. Data are presented as means $\pm \operatorname{SD}(n=5)$. Different letters indicate sample groups with significant differences $(p<0.05)$ from each other.

Fig. S7. Profiling of phosphotidic acid species in Col-0, pld $\beta 1-1$, and pld $\beta 1-1$ complementation Arabidopsis plants inoculated with control solutions (-C) or with pathogens (-T). Control solutions were water for Botrytis cinerea spores and $10 \mathrm{mM} \mathrm{MgSO}_{4}$ for virulent strain Pst DC3000 and avirulent strain Pst DC3000 (avrRpt2) (all pathogen suspensions are $2 \times 10^{7} \mathrm{cfu} / \mathrm{mL}$ ). Leaf samples were collected for lipid profiling $24 \mathrm{~h}$ post inoculation. Values are means $\pm \mathrm{SE}(\mathrm{n}=5)$. Different letters indicate sample groups with significant differences $(\mathrm{P}<0.05)$ from each other.

Fig. S8. Profiling of PC (A) and PE (B) species in Col-0, pld 1 1-1, and pld $\beta 1-C O M$ Arabidopsis plants inoculated with control solutions (-C) or with pathogens (-T). Control solutions were water for Botrytis cinerea spores and $10 \mathrm{mM} \mathrm{MgSO}_{4}$ for virulent strain Pst DC3000 and avirulent strain Pst DC3000 (avrRpt2) (all pathogen suspensions are $2 \times 10^{7} \mathrm{cfu} / \mathrm{mL}$ ). Leaf samples were collected for lipid profiling $24 \mathrm{~h}$ post inoculation. Values are means \pm SE $(n=5)$. Different letters indicate sample groups with significant differences $(p<0.05)$ from each other.

Fig. S9. Profiling of LPG species from Arabidopsis leaves of Col-0, pldß1-1, and pldß1-COM plants with and without inoculation of $B$. cinerea, Pst DC3000, or avirulent Pst DC3000 (avrRpt2). Col-0, pld $\beta 1-1$, and pld $\beta 1-\mathrm{COM}$ plant were inoculated with control solutions (-C) or with pathogens (-T). Control solutions were water for Botrytis cinerea and $10 \mathrm{mM} \mathrm{MgSO}$ for virulent 
strain Pst DC3000 and avirulent strain Pst DC3000 (avrRpt2) (all pathogen suspensions are $2 \times 10^{7}$ $\mathrm{cfu} / \mathrm{mL})$. Leaf samples were collected for lipid profiling $24 \mathrm{~h}$ post inoculation. Values are means $\pm \mathrm{SE}$ $(\mathrm{n}=5)$. Different letters indicate sample groups with significant differences $(\mathrm{P}<0.05)$ from each other.

(A) LPC species from Col-0, pld $\beta 1-1$, and pld $\beta 1$ complementation (COM) plants under different treatments.

(B) LPE species from Col-0, pld $\beta 1-1$, and pld $\beta 1$ complementation (COM) plants under different treatments.

(B) LPG species from Col-0, pld $\beta 1-1$, and pld $\beta 1$ complementation (COM) plants under different treatments.

Supplemental data Table S1. Real time PCR primers

\begin{tabular}{|c|c|c|c|}
\hline Primer Names & $5^{\prime}-3^{\prime}$ sequences & Genes & $\begin{array}{l}\text { Fragment } \\
\text { size (bp) }\end{array}$ \\
\hline PLD $\beta 1$ Forward & CGGAGGTAACATTGTCGGATC & \multirow{2}{*}{ AT2G42010 } & \multirow{2}{*}{141} \\
\hline PLD $\beta 1$ Reverse & TCTCССАСССТСТТАТТАТСА & & \\
\hline PR1 F & TTCTTCCCTCGAAAGCTCAA & \multirow{2}{*}{ AT2G14610 } & \multirow{2}{*}{173} \\
\hline PR1 R & AAGGCCCACCAGAGTGTATG & & \\
\hline UBQ5 F & ACCAAGCCGAAGAAGATCA & \multirow[b]{2}{*}{ AT3G62250 } & \multirow{2}{*}{194} \\
\hline UBQ5 R & GTAAACGTAGGTGAGTCCA & & \\
\hline PDF12 F & CTT GTT CTC TTT GCT GCT TTCG & \multirow{2}{*}{ AT5G44420 } & \multirow{2}{*}{154} \\
\hline PDF12 R & CAT GTT TGG CTC CTT CAA G & & \\
\hline LOX2 F & TGAAAGATTCAAAGGCAAGCT & \multirow{2}{*}{ AT3G45140 } & \multirow{2}{*}{151} \\
\hline LOX2 R & GAACACCCATTCCGGTAACA & & \\
\hline $\mathrm{AOS} F$ & CATGTGTTGTGGTCGAATGGA & \multirow{2}{*}{ AT5G42650 } & \multirow{2}{*}{174} \\
\hline AOS R & ATTAACGGAGCTTCCTAACG & & \\
\hline Tubulin8 F & GACATTTGGCTATGTGTGATG & \multirow{2}{*}{ AT5G23860 } & \multirow{2}{*}{136} \\
\hline Tubulin8 R & CAGATGGAATCACCAACGTTT & & \\
\hline PLD $\beta 2 F$ & CTGCTAGATGATTGCTTTGT & \multirow[b]{2}{*}{ AT4G00240 } & \multirow{2}{*}{108} \\
\hline PLD $\beta 2 R$ & CTCCGACACTTCCTCACTC & & \\
\hline
\end{tabular}




\section{FIGURE LEGENDS}

Figure 1. Production and Confirmation of $P L D \beta 1$ RNAi Knockdown and T-DNA Insertion Knockout Arabidopsis Lines.

(a) Construction of $P L D \beta$ RNAi vector. Inverted repeats of exons (gray boxes) and an intron (empty boxes) with restriction sites were cloned in tandem, and their expression was driven by double CaMV $35 \mathrm{~S}$ promoters and terminated by an NOS terminator.

(b) RNA blotting of $P L D \beta 1$ and $P L D \alpha 1$ expression in $R N A i$ lines. Equal amounts of total RNA from Arabidopsis leaves were loaded and rRNA detected with ethidium bromide (EtBr) was used as loading control. PLD $\alpha 1$ protein levels were also used as loading controls. The density of the PLD $\beta 1$ RNA band was quantified from three experiments. Data bars represent the mean $( \pm \mathrm{SD})$ of three repeats.

(c) Immunoblotting of PLD $\beta 1$ and PLD $\alpha 1$ protein levels in RNAi lines. Equal amounts of Arabidopsis leaf proteins were subjected to SDS-PAGE, followed by immunoblotting using antibodies against PLD $\beta 1$ and PLD $\alpha 1$. The band density of PLD $\beta 1$ was quantified from three experiments. Data bars represent the mean $( \pm \mathrm{SD})$ of three repeats.

(d) T-DNA insertional knockout of $P L D \beta 1$. Left panel, T-DNA insertion position in $P L D \beta 1$ with exons (gray boxes) and introns (bars between exons). Right panel, northern blot showing the absence of the $P L D \beta 1$ transcript in T-DNA insertion knockout. PLD $\alpha 1$ expression and 28S RNA (detected with ethidium bromide) were used as loading controls.

\section{Figure 2. Responses of $P L D \beta 1$ Arabidopsis Mutants to Bacterial Pathogens}

Fully expanded leaves of Col-0, pld $\beta 1-1$, RNAi mutants, and pld $\beta 1-1$ complementation (COM) plants were infiltrated with a suspension containing Pst DC3000 with or without avrRpt2.

(a) Expression of $P L D \beta 1$ and $P L D \beta 2$ in Col-0 plants infected with Pst DC3000 pathogens or Pst DC3000(avr Rpt2) pathogens (2 x $107 \mathrm{cfu} / \mathrm{mL})$ for $12 \mathrm{~h}$. Leaves treated with $10 \mathrm{mM} \mathrm{MgSO} 4$ were used as a control (mock). The relative expression level of $P L D \beta 1$ and $P L D \beta 2$ was analyzed by quantitative PCR. Expression levels were normalized with respect to the housekeeping genes $U B Q$ and Tubulin. Data bars represent the mean $( \pm \mathrm{SD})$ of three repeats.

(b) Defensive response of Arabidopsis plants with altered $P L D \beta 1$ expression to virulent and avirulent Pst DC3000 (2 x $\left.10^{7} \mathrm{cfu} / \mathrm{mL}\right)$. The photographs show representative leaves inoculated with bacterial pathogen for $12 \mathrm{~h}$. 
(c) Proliferation of the virulent Pst DC3000 (left panel) and avirulent Pst DC3000 (avrRpt2) (2 x $10^{5}$ $\mathrm{cfu} / \mathrm{mL}$ ) (right panel) pathogens in Col-0, pldß1-1, RNAi plants. Bacterial growth in five leaf discs was measured. The bacterial numbers expressed as the increase of colony-forming units (cfu) per leaf disc after bacterial inoculation (i.e. Log cfu post inoculation- Log cfu at time zero). Data represent the average of three samples \pm SD. Different letters indicate sample groups with significant differences $(p$ $<0.05)$ from each other.

\section{Figure 3. Salicylic Acid in Pathogen-Inoculated PLDß1 Arabidopsis Mutants}

Total SA (free SA + SA Glycosides) in the wild-type, pld $\beta 1-1, R N A i 1$, and RNAi2 were determined by HPLC. Data are presented as means \pm SD $(n=3)$. Different letters indicate sample groups with significant differences $(p<0.05)$ from each other.

(a) SA levels in inoculated leaves as a function of time post $P$ st DC3000 inoculation $\left(2 \times 10^{7} \mathrm{cfu} / \mathrm{ml}\right)$.

(b) SA levels in leaves from local and distal leaves from Pst DC3000-inoculated plants for $12 \mathrm{~h}$.

(c) Expression of defense-related genes in Col-0, pldB1-1, RNAi1, RNAi2, and pld $\beta 1-1$ complementation (COM) plants infected with Pst DC3000 pathogens (pst) or Pst DC3000(Avr Rpt2) (Rpt) pathogens $(2 \times 107 \mathrm{cfu} / \mathrm{mL})$ for $12 \mathrm{~h}$. Leaves treated with $10 \mathrm{mM} \mathrm{MgSO} 4(\mathrm{~m})$ were used as a control. The relative expression level of $P R-1$ was analyzed by quantitative PCR. Expression levels were normalized with respect to the housekeeping genes. Data bars represent the mean $( \pm \mathrm{SD})$ of three repeats.

\section{Figure 4. Responses of $P L D \beta 1$ Arabidopsis Mutants to $B$. cinerea}

(a) Leaves of three week-old Col-0, pld $\beta 1-1, R N A i$, and pld $\beta 1$-1-complementation (COM) plants were inoculated with $B$. cinerea spores $\left(5 \times 10^{7}\right.$ spores $\left./ \mathrm{ml}\right)$ or water (control). The photographs show representative leaves 5 days post-inoculation.

(b) Lesions scored at 5 days post inoculation. The lesion developing rate was the number of leaves with a necrotic area among the inoculated leaves in each line. Data are presented as mean \pm SD $(n=$ 25). Different letters indicate sample groups with significant differences $(p<0.05)$ from each other.

(c) Expression of defense-related genes in Col-0 and $P L D \beta 1$ mutants infected with fungal pathogens by quantitative PCR. Expression levels were normalized with respect to ubiquitin 5 (UBQ5). Data bars represent the mean $( \pm \mathrm{SD})$ of three repeats. Leaves treated with water were used as control. 
(d) JA levels in wild-type (Col-0), pld $\beta 1-1$, and pld $\beta 1$-complementation (COM) plants at various hours post inoculation (hpi) with B. cinerea. $\mathrm{C}$ indicates control (i.e. mock-inoculated) and $\mathrm{T}$ indicated treated (i.e. pathogen-inoculated). Three week-old soil-grown seedlings were treated with B. cinerea spores. Values are means $\pm \mathrm{SE}$ of three independent replicate experiments.

(e) Salicylic acid in Botrytis cinerea spore-inoculated PLD 1 mutants. Samples were harvested after inoculation Botrytis cinerea spores $\left(5 \times 10^{7} \mathrm{cfu} / \mathrm{ml}\right)$ for different time. Total SA (free SA + SA Glycosides) in the wild-type, pld $\beta 1-1, R N A i 1, R N A i 2$, and pld $\beta 1-1$ complementation plants were determined by HPLC. Data are presented as means $\pm \operatorname{SD}(\mathrm{n}=3)$.

\section{Figure 5. ROS Generation in Arabidopsis Response to Pathogen Infection.}

The wild-type (Col-0), pldB1-1, RNAil, and RNAi2 plants were inoculated with Pst DC3000 (2 x $10^{7}$ $\mathrm{cfu} / \mathrm{ml})$ or Botrytis cinerea spores. Data are presented as means $\pm \mathrm{SD}(\mathrm{n}=5)$.

(a) Nitroblue tetrazolium staining of 5-week old Arabidopsis leaves $12 \mathrm{~h}$ post inoculation with Pst DC3000 bacterial pathogen $\left(2 \times 10^{7} \mathrm{cfu} / \mathrm{ml}\right)$.

(b) $\mathrm{H}_{2} \mathrm{O}_{2}$ quantification in Pst DC3000-infected leaves $12 \mathrm{~h}$ post inoculation.

(c) Nitroblue tetrazolium staining of 5-week old Arabidopsis leaves $12 \mathrm{~h}$ post inoculation with $B$. cinerea.

(d) $\mathrm{H}_{2} \mathrm{O}_{2}$ quantification in $B$. cinerea spore-inoculated leaves.

Different letters indicate sample groups with significant differences $(p<0.05)$ from each other.

Figure 6. Phospholipid and Galactolipid Content from Leaves of Wild-type and pldß1-1 Arabidopsis as affected by $B$. cinerea, Pst DC3000, or Avirulent Pst DC3000 (avrRpt2) Infection. Col-0, pld $\beta 1-1$, and pld $\beta 1$ complementation (COM) plant were inoculated with control solutions (-C) or with pathogens (-T). Control solutions were water for Botrytis cinerea spores ( $5 \times 10^{7}$ spores $\left./ \mathrm{ml}\right)$ and $10 \mathrm{mM} \mathrm{MgSO}_{4}$ for virulent strain Pst DC3000 and avirulent strain Pst DC3000 (avrRpt2) $\left(2 \times 10^{7}\right.$ $\mathrm{cfu} / \mathrm{ml})$. Leaf samples were collected for lipid profiling $24 \mathrm{~h}$ post inoculation. Values are means $\pm \mathrm{SE}$ $(\mathrm{n}=5)$. Different letters indicate sample groups with significant differences $(p<0.05)$ from each other. 
Figure 7. Levels of total LPC, LPE, and LPG from Leaves of Wild-type and pldß1-1 Arabidopsis with and without Inoculation of $B$. cinerea, Pst DC3000, or avirulent Pst DC3000 (avrRpt2).

Col-0, pld $\beta 1-1$, and pld $\beta 1-\mathrm{COM}$ plant were inoculated with control solutions (-C) or with pathogens (T). Control solutions were water for Botrytis cinerea and $10 \mathrm{mM} \mathrm{MgSO}_{4}$ for virulent strain Pst DC3000 and avirulent strain Pst DC3000 (avrRpt2). Leaf samples were collected for lipid profiling $24 \mathrm{~h}$ post inoculation. Values are means of $\pm \mathrm{SE}(\mathrm{n}=5)$. Different letters indicate values with significant differences $(\mathrm{P}<0.05)$ from each other. 
(a)

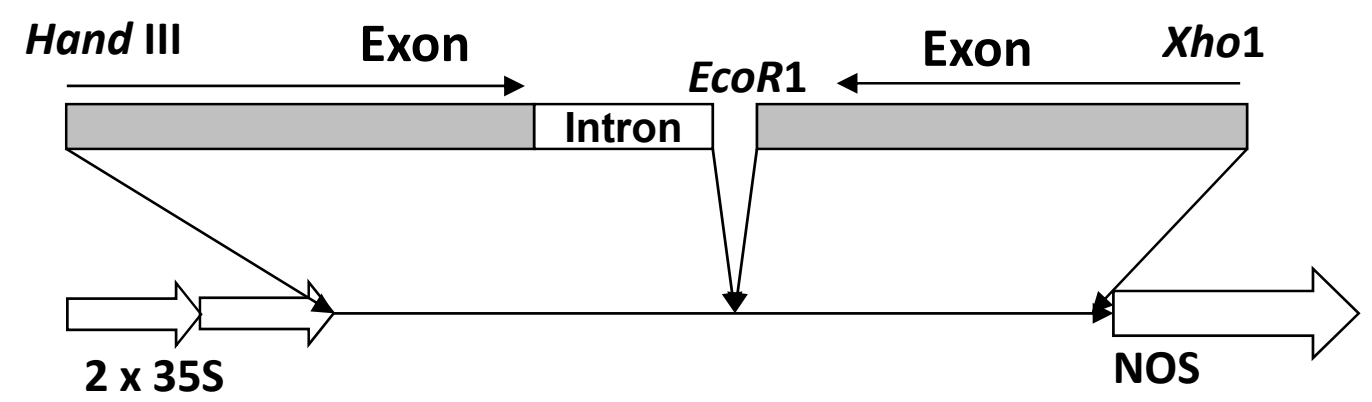

(b)

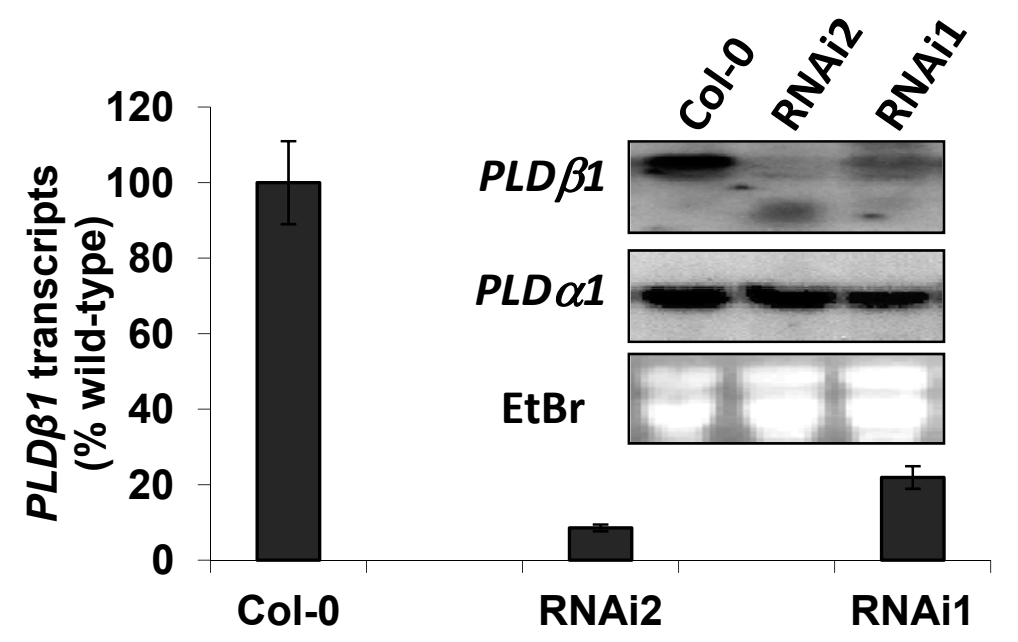

(c)

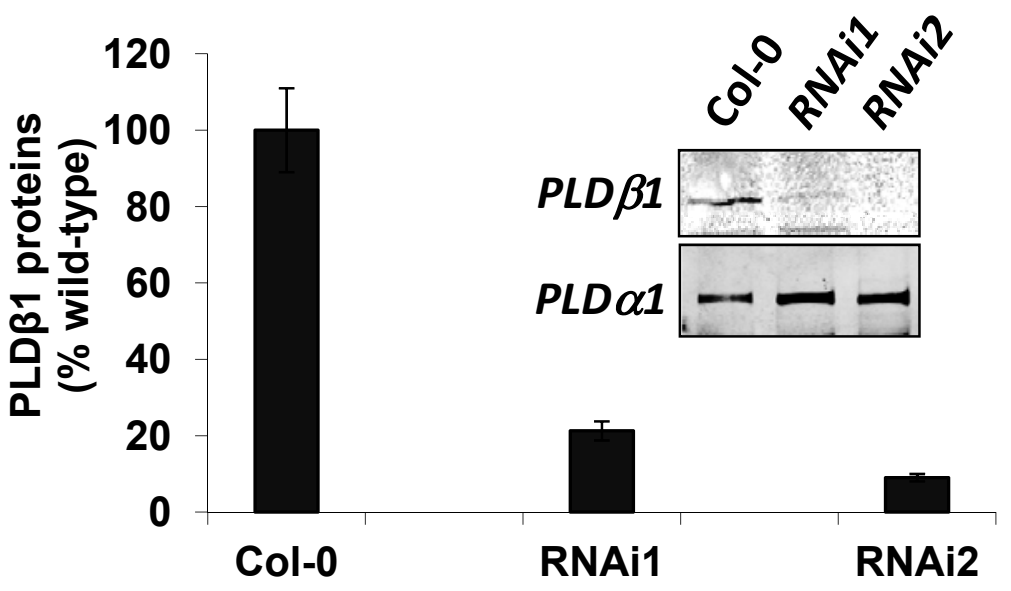

(d)
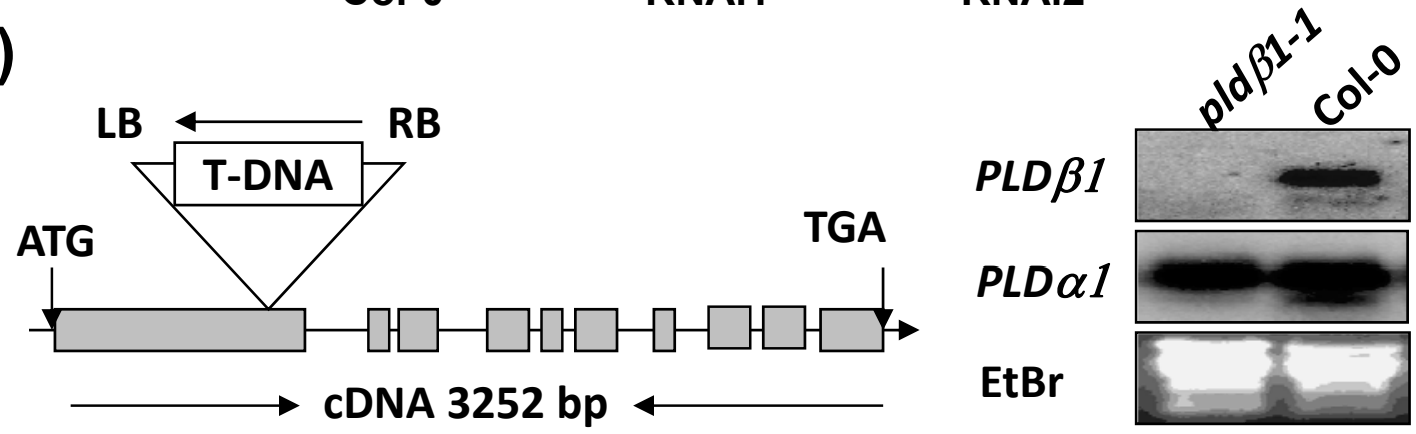
Figure 1. Production and Confirmation of PLDB1 RNAi Knockdown and T-DNA Insertion Knockout Arabidopsis Lines.

(a) Construction of $P L D \beta$ RNAi vector. Inverted repeats of exons (gray boxes) and an intron (empty boxes) with restriction sites were cloned in tandem, and their expression was driven by double CaMV $35 \mathrm{~S}$ promoters and terminated by an NOS terminator. (b) RNA blotting of $P L D \beta 1$ and $P L D \alpha 1$ expression in $R N A i$ lines. Equal amounts of total RNA from Arabidopsis leaves were loaded and rRNA detected with ethidium bromide (EtBr) was used as loading control. $P L D \alpha 1$ expression levels were also used as loading controls. The density of the $P L D \beta 1$ RNA band was quantified from three repeat experiments.

(c) Immunoblotting of PLD $\beta 1$ and PLD $\alpha 1$ protein levels in $R N A i$ lines. Equal amounts of Arabidopsis leaf proteins were subjected to SDS-PAGE, followed by immunoblotting using antibodies against PLD $\beta 1$ and PLD $\alpha 1$. The band density of PLD $\beta 1$ was quantified from three repeat experiments.

(d) T-DNA insertional knockout of $P L D \beta 1$. Top panel, T-DNA insertion position in $P L D \beta 1$ with exons (gray boxes) and introns (bars between exons). Bottom panel, northern blot showing the absence of the $P L D \beta 1$ transcript in T-DNA insertion knockout. $P L D \alpha 1$ expression and 28S RNA (detected with ethidium bromide) were used as loading controls. 
(a)
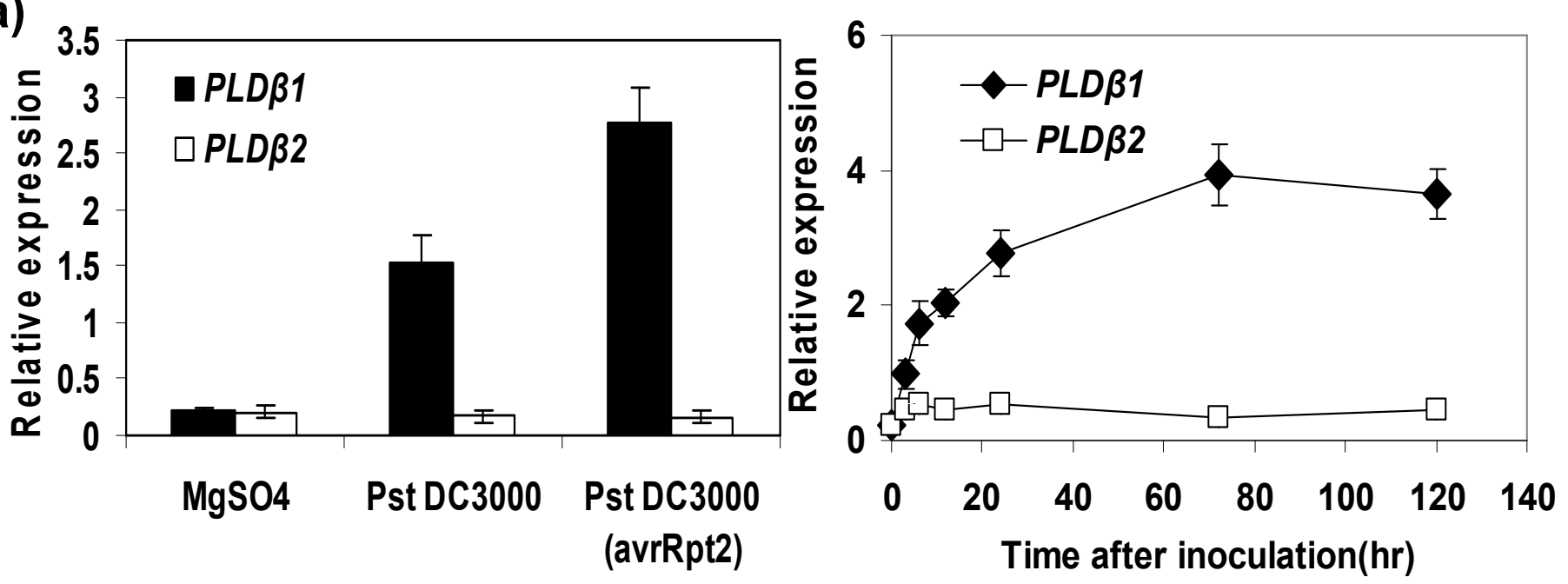

(b)
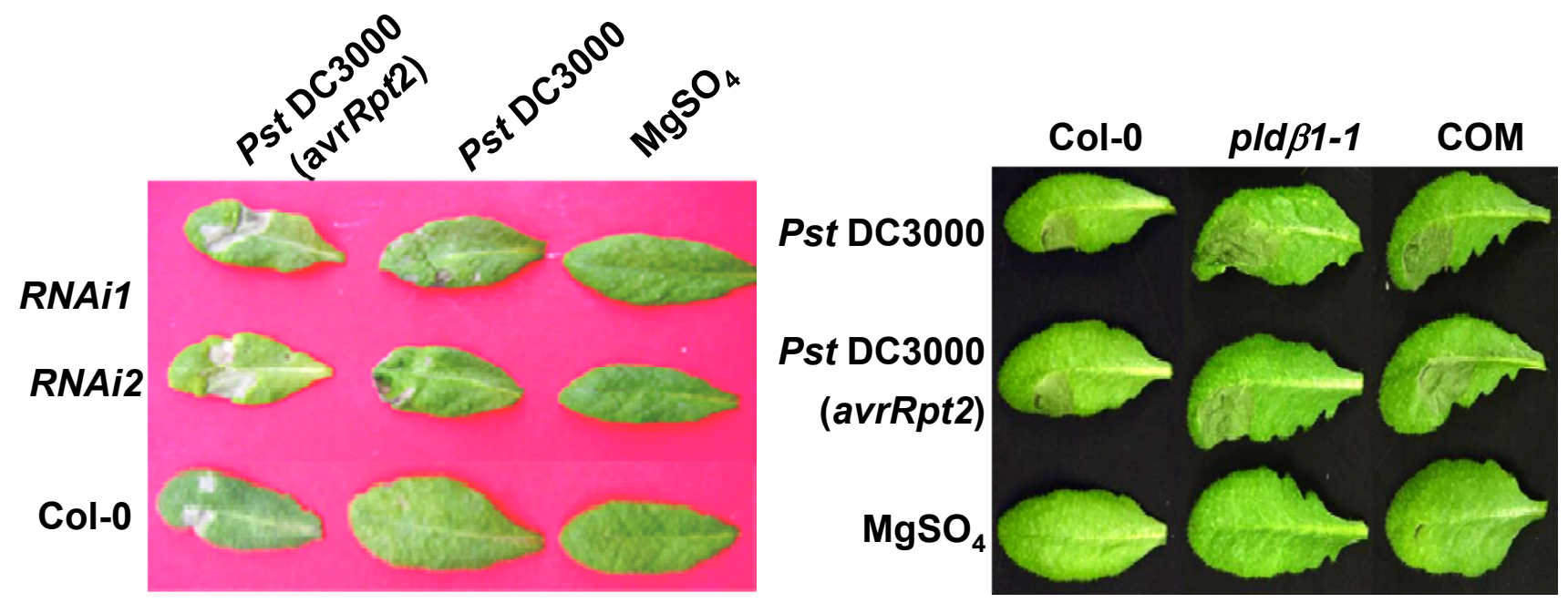

(c)
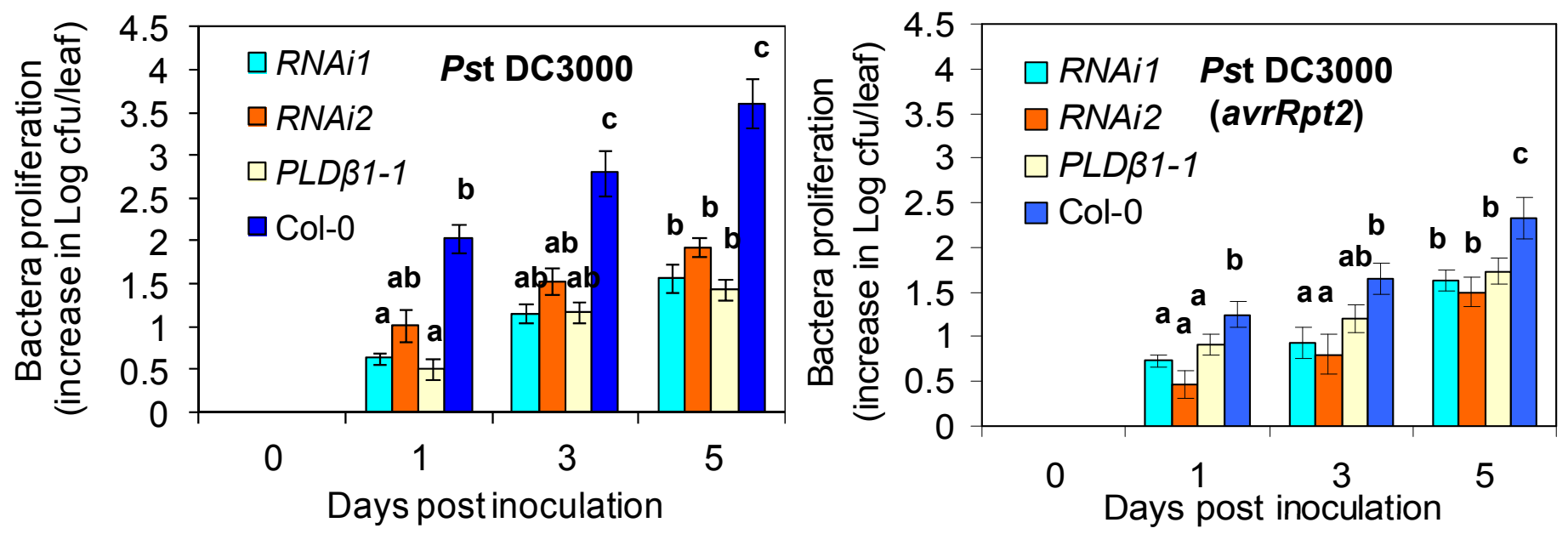

Figure 2 


\section{Figure 2. Responses of $P L D \beta 1$ Arabidopsis Mutants to Bacterial Pathogens}

Fully expanded leaves of Col-0, pld $\beta 1-1$, RNAi mutants, and pld $\beta 1-1$ complementation (COM) plants were infiltrated with a suspension containing Pst DC3000 with or without avrRpt2.

(a) Expression of $P L D \beta 1$ and $P L D \beta 2$ in Col-0 plants infected with Pst DC3000 pathogens or Pst DC3000(avrRpt2) pathogens ( $2 \times 107 \mathrm{cfu} / \mathrm{mL})$ for $12 \mathrm{~h}$ (left penal). Time-course expression of $P L D \beta 1$ and $P L D \beta 2$ infected with Botrytis cinerea spores $\left(2 \times 10^{7} \mathrm{cfu} / \mathrm{ml}\right)($ right panel). Leaves treated with $10 \mathrm{mM} \mathrm{MgSO} 4$ were used as a control (mock). The relative expression level of $P L D \beta 1$ and $P L D \beta 2$ was analyzed by quantitative PCR. Expression levels were normalized with respect to the housekeeping genes $U B Q 5$ and Tubulin. Data bars represent the mean $( \pm \mathrm{SD})$ of three repeats.

(b) Defensive response of Arabidopsis plants with altered $P L D \beta 1$ expression to virulent and avirulent $P$ st DC3000 $\left(2 \times 10^{7} \mathrm{cfu} / \mathrm{mL}\right)$. The photographs show representative leaves inoculated with bacterial pathogen for $12 \mathrm{~h}$.

(c) Proliferation of the virulent Pst DC3000 (left panel) and avirulent Pst DC3000 (avrRpt2) (right panel) $\left(2 \times 10^{5} \mathrm{cfu} / \mathrm{ml}\right)$ pathogens in Col-0, pld $\beta 1-1$, RNAi plants. Bacterial growth in five leaf discs was measured. The bacterial numbers expressed as the increase of colonyforming units (cfu) per leaf disc after bacterial inoculation (i.e. Log cfu post inoculation- Log cfu at time zero). Data represent the average of three samples $\pm \mathrm{SD}$. Different letters indicate sample groups with significant differences $(p<0.05)$ from each other. 
(a

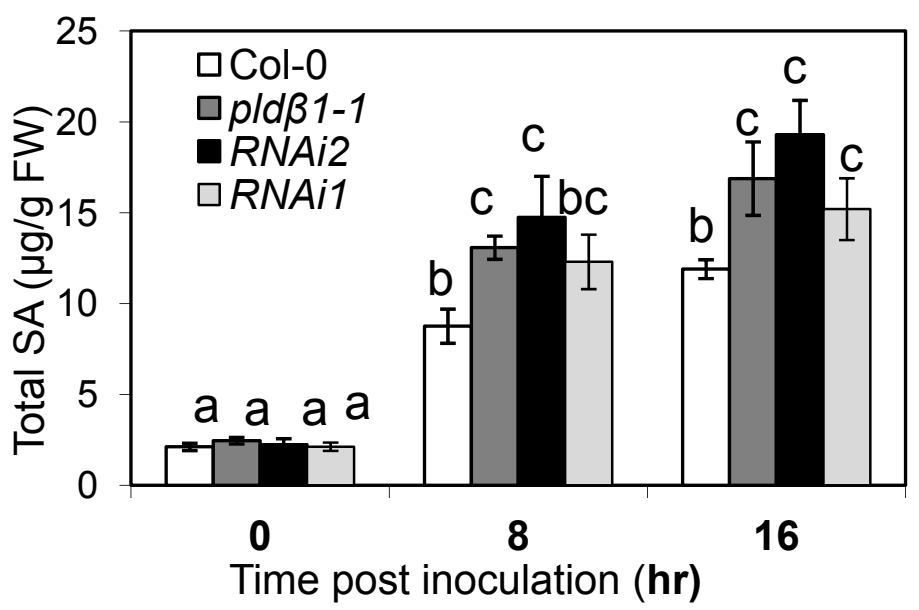

(b)

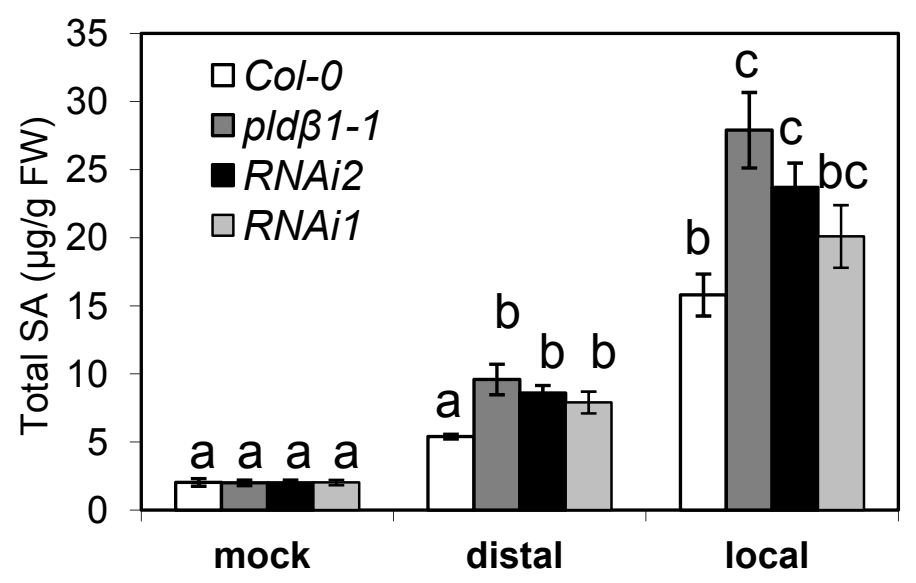

(c)
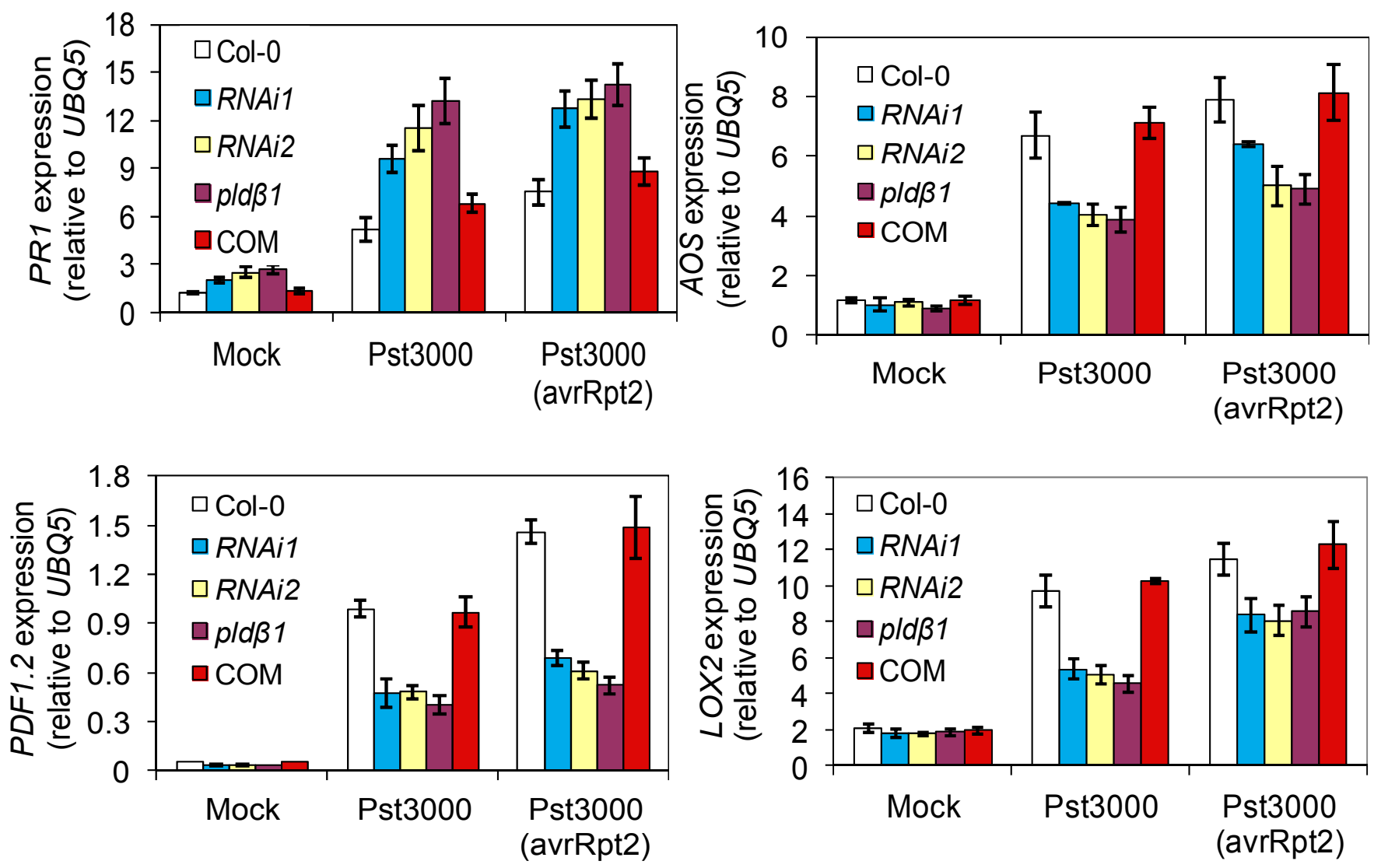


\section{Figure 3. Salicylic Acid in Pathogen-Inoculated $P L D \beta 1$ Arabidopsis Mutants}

Total SA (free SA + SA Glycosides) in the wild-type , pld $\beta 1-1, R N A i 1$, and RNAi2 were determined by HPLC. Data are presented as means $\pm \mathrm{SD}(\mathrm{n}=3)$. Different letters indicate sample groups with significant differences $(p<0.05)$ from each other.

(A) SA levels in inoculated leaves as a function of time post Pst DC3000 inoculation $\left(2 \times 10^{7}\right.$ $\mathrm{cfu} / \mathrm{ml})$.

(B) SA levels in leaves from local and distal leaves from Pst DC3000-inoculated plants for $12 \mathrm{~h}$.

(C) Expression of defense-related genes in Col-0, pld $\beta 1-1$, RNAi1, RNAi2, and pld $\beta 1-1$

complementation (COM) plants infected with Pst DC3000 pathogens or Pst DC3000(avr Rpt2) pathogens $(2 \times 107 \mathrm{cfu} / \mathrm{ml})$ for $12 \mathrm{~h}$. Leaves treated with $10 \mathrm{mM} \mathrm{MgSO}_{4}$ were used as a control. The relative expression level of $P R-1$ was analyzed by quantitative PCR. Expression levels were normalized with respect to the housekeeping genes $U B Q 5$. Data bars represent the mean $\pm \mathrm{SD}$ of three repeats. 
(a)

B. cinerea spores

Control

B. cinerea spores

(c)
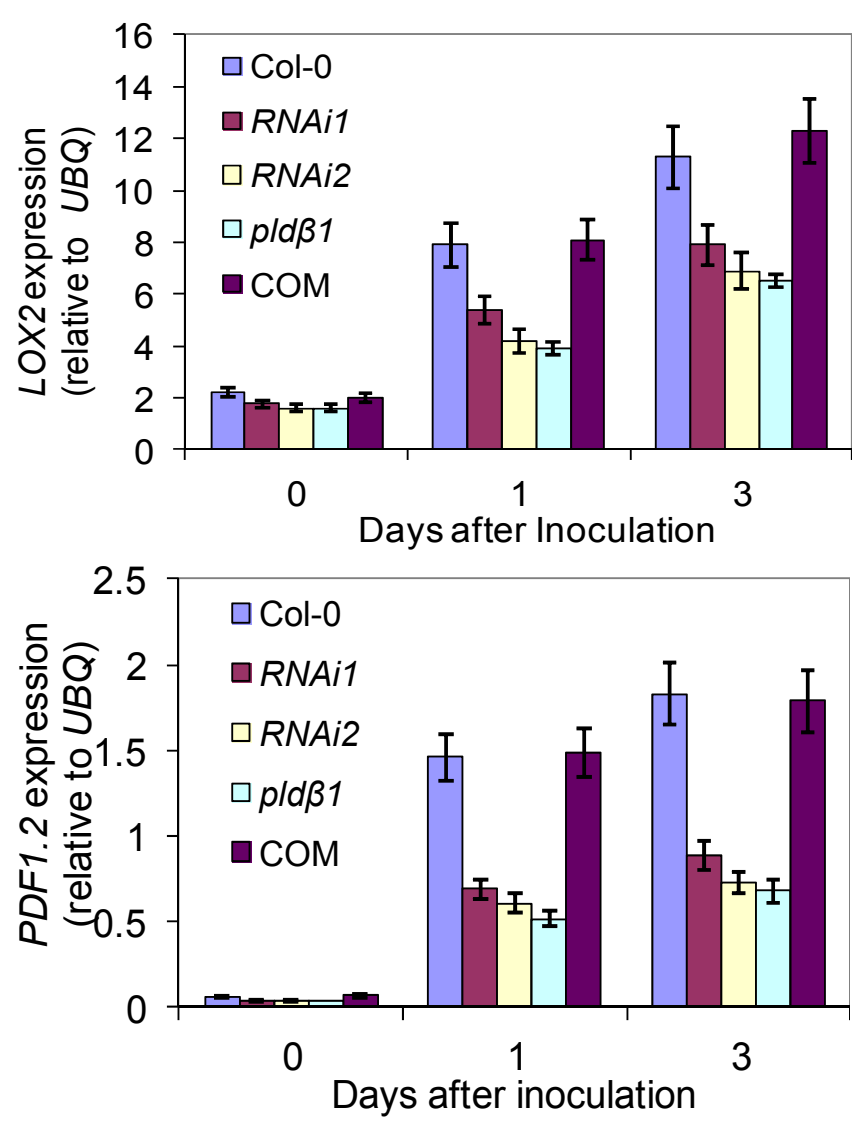

(d)

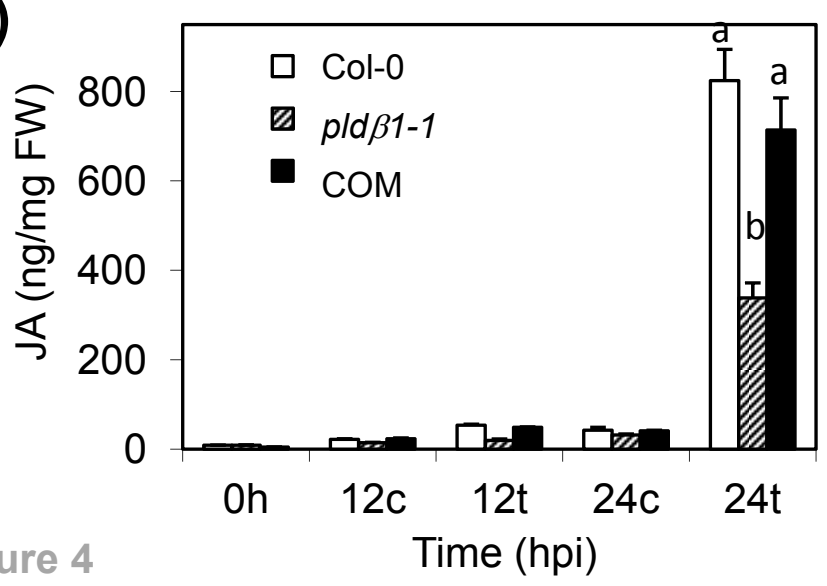

(b)
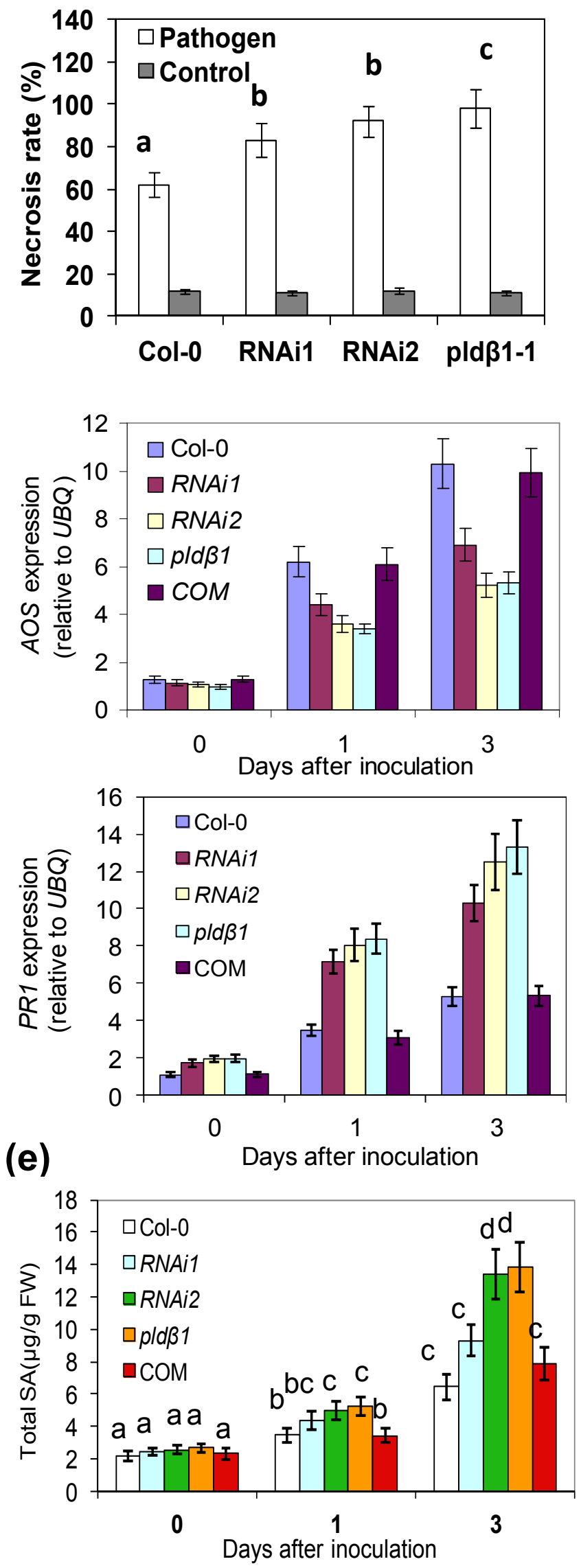
Figure 4. Responses of $P L D \beta 1$ Arabidopsis Mutants to $B$. cinerea

(a) Leaves of three week-old Col-0, pld $\beta 1-1, R N A i$, and pld $\beta 1$-1-complementation (COM) plants were inoculated with $B$. cinerea spores $\left(2 \times 10^{7} \mathrm{cfu} / \mathrm{ml}\right)$. or water (control). The photographs show representative leaves 5 days post-inoculation.

(b) Lesions scored at 5 days post inoculation. The lesion developing rate was the number of leaves with a necrotic area among the inoculated leaves in each line. Data are presented as mean $\pm \mathrm{SD}(\mathrm{n}=25)$. Different letters indicate sample groups with significant differences $(p$ $<0.05)$ from each other.

(c) Expression of defense-related genes in Col-0 and PLD $\beta 1$ mutants infected with fungal pathogens. Leaves treated with water were used as control. The relative expression level of $P R-1$ was analyzed by quantitative PCR. Expression levels were normalized with respect to the housekeeping genes. Data bars represent the mean $( \pm \mathrm{SD})$ of three repeats.

(d) JA levels in Arabidopsis wild-type (Col-0), pld $\beta 1$-1, and pld $\beta 1$ complementation (COM) plants with infection with $B$. cinerea for various hours post inoculation (hpi). $\mathrm{C}$ indicates control (i.e. mock-inoculated) and $\mathrm{T}$ indicated treated (i.e. pathogen-inoculated). Three weekold soil-grown seedlings were treated with $B$. cinerea spores. Values are means \pm SE of three independent replicate experiments.

(e) Salicylic acid in Botrytis cinerea spore-inoculated PLD $\beta 1$ mutants. Samples were harvested after inoculation Botrytis cinerea spores $\left(5 \times 10^{7} \mathrm{cfu} / \mathrm{m} 1\right)$ for different time. Total $\mathrm{SA}$ (free SA + SA Glycosides) in the wild-type, pld $\beta 1-1$, RNAi1, RNAi2, and pld $\beta 1-1$ complementation plants were determined by HPLC. Data are presented as means \pm SD $(\mathrm{n}=$ 3). 
(a)

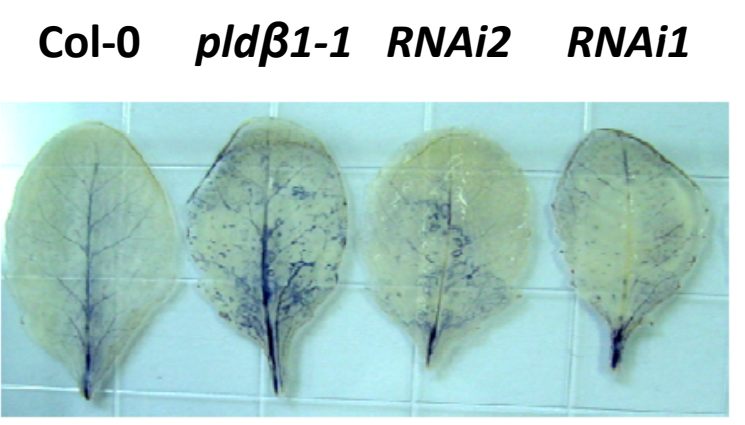

(c)

\section{Col-0 pldß1-1 RNAi2 RNAi1}

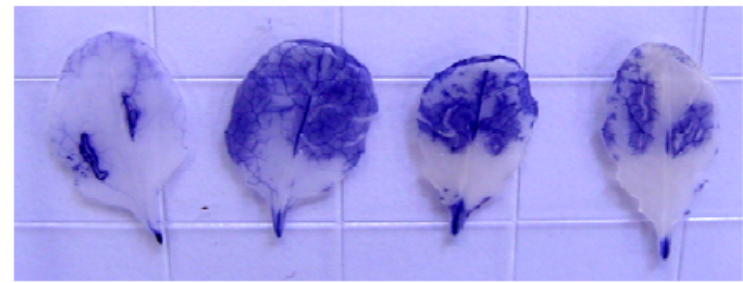

(b)

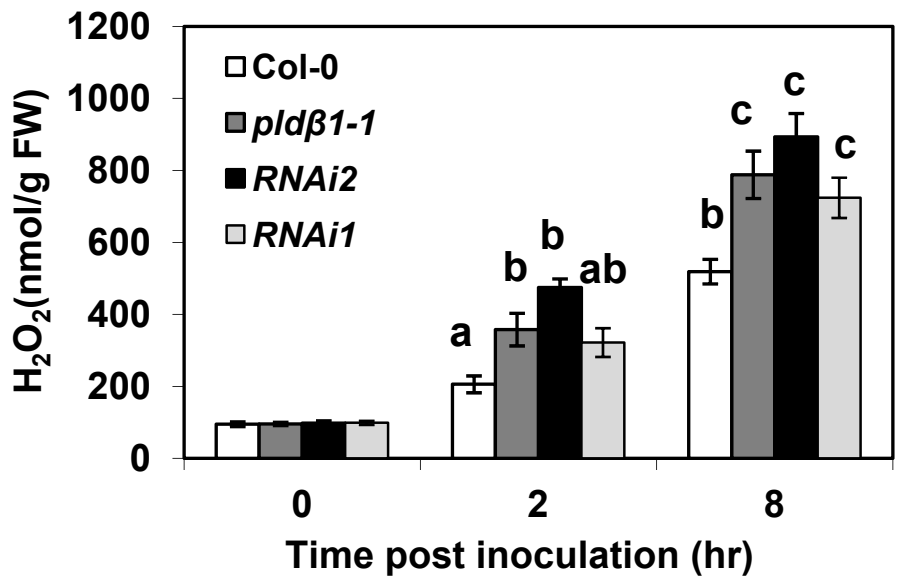

(d)

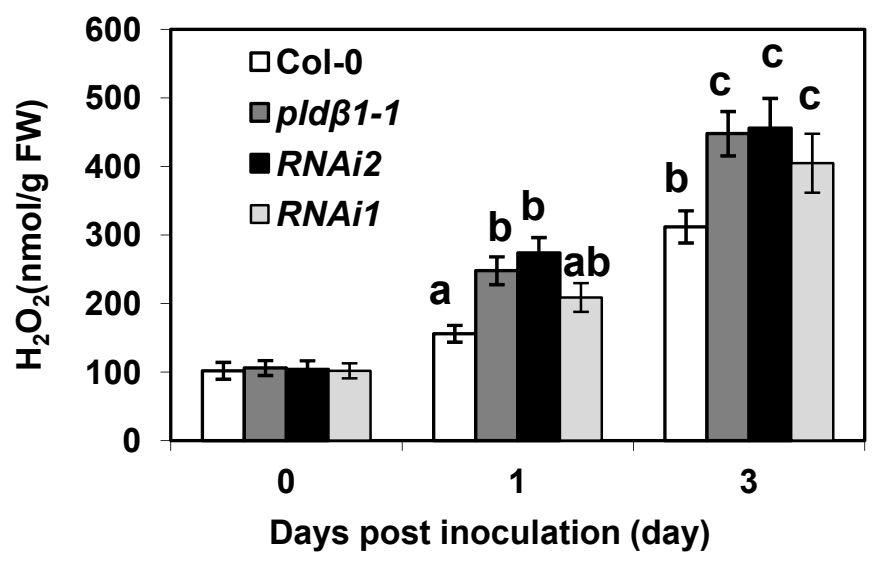

Figure 5. ROS Generation in Arabidopsis Responses to Pathogen Infection.

The wild-type (Col-0), pld $\beta 1-1, R N A i 1$, and RNAi2 plants were inoculated with Pst DC3000 (2 x $\left.10^{7} \mathrm{cfu} / \mathrm{ml}\right)$ or Botrytis cinerea spores. Data are presented as means $\pm \mathrm{SD}(\mathrm{n}=5)$.

(a) Nitroblue tetrazolium staining of 5-week old Arabidopsis leaves $12 \mathrm{~h}$ post inoculation with Pst DC3000 bacterial pathogen.

(b) $\mathrm{H}_{2} \mathrm{O}_{2}$ quantification in Pst DC3000-infected leaves $12 \mathrm{~h}$ post inoculation.

(c) Nitroblue tetrazolium staining of 5-week old Arabidopsis leaves $12 \mathrm{~h}$ post inoculation with $B$. cinerea.

(d) $\mathrm{H}_{2} \mathrm{O}_{2}$ quantification in $B$. cinerea spores-inoculated leaves.

Different letters indicate values with significant differences $(p<0.05)$ from each other. 


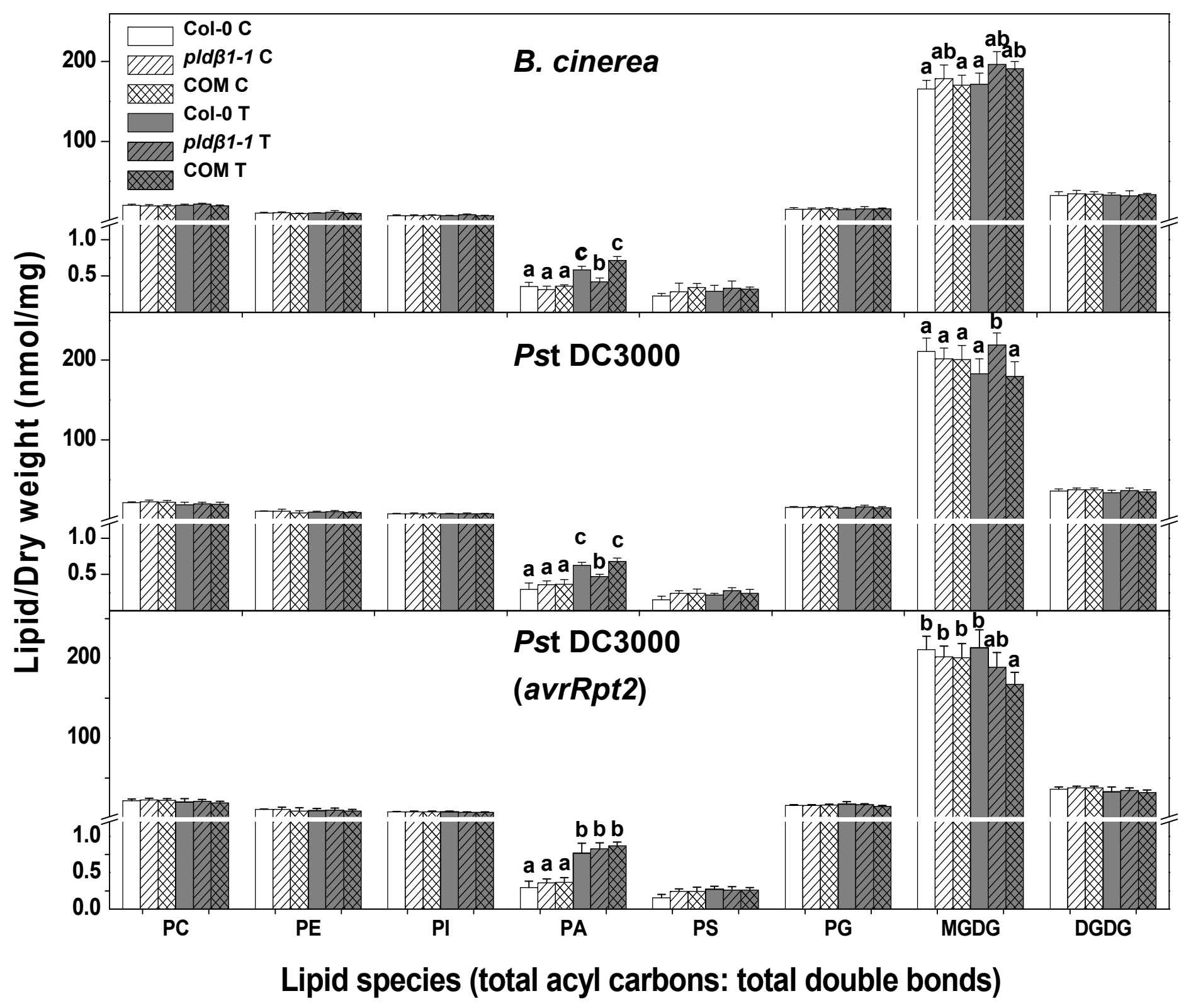

Figure 6. Content of different phospholipid and galactolipid classes from leaves of Col-0, pld $\beta 1$-1, and pldß1-COM Arabidopsis plants with and without inoculation of $B$. cinerea, Pst DC3000, or avirulent Pst DC3000 (avrRpt2).

Col-0, pld $\beta 1-1$, and pld $\beta 1$ complementation (COM) plant were inoculated with control solutions (-C) or with pathogens (-T). Control solutions were water for Botrytis cinerea and $10 \mathrm{mM} \mathrm{MgSO}_{4}$ for virulent strain Pst DC3000 and avirulent strain Pst DC3000 (avrRpt2). Leaf samples were collected for lipid profiling $24 \mathrm{~h}$ post inoculation. Values are means $\pm S E(n=5)$. Different letters indicate sample groups with significant differences $(p<0.05)$ from each other. 


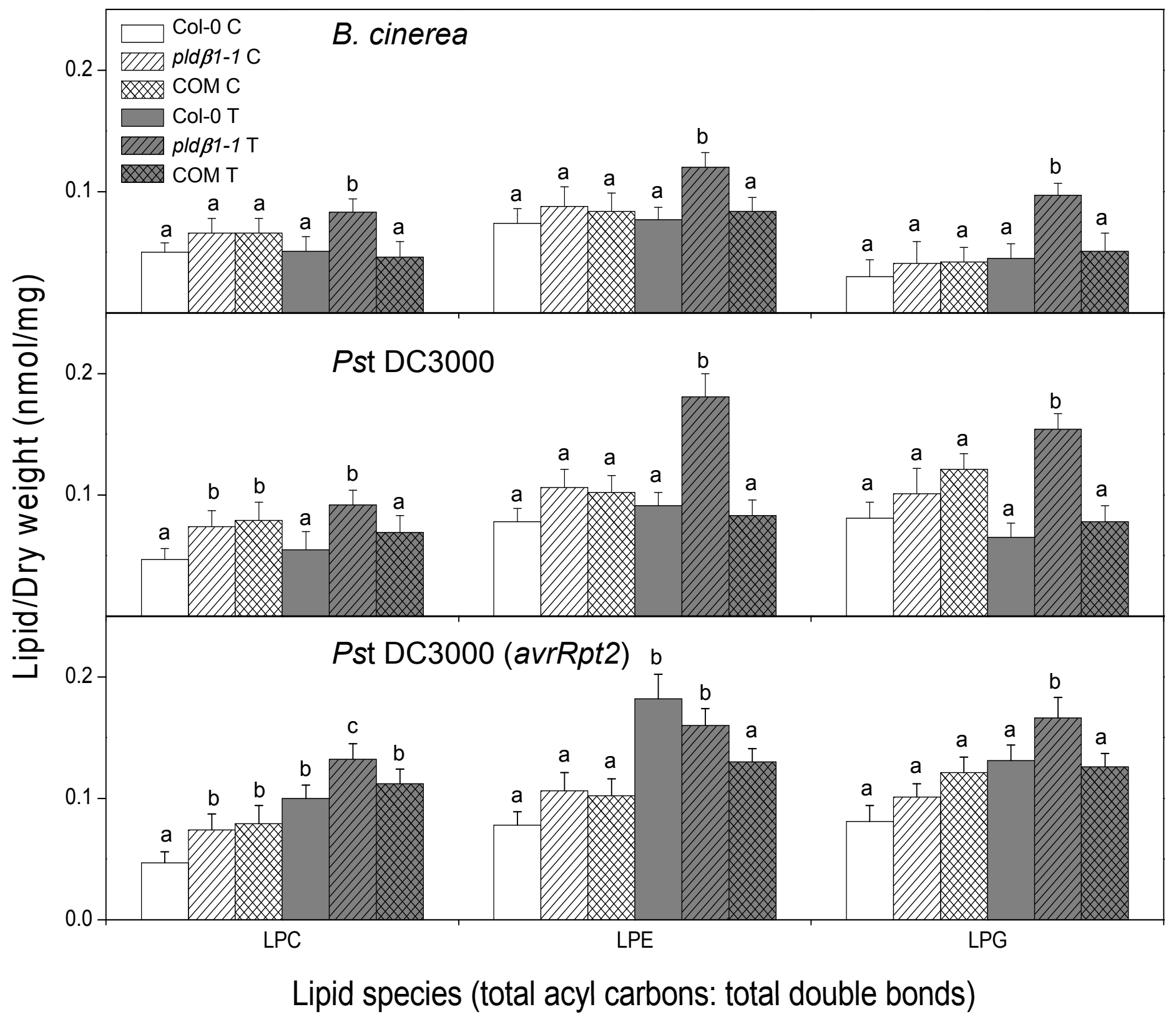

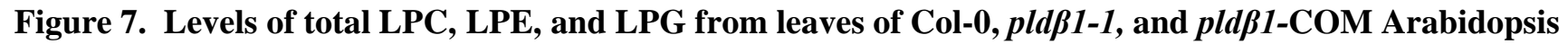
plants with and without inoculation of $B$. cinerea, Pst DC3000, or avirulent Pst DC3000 (avrRpt2).

Col-0, pld $\beta 1-1$, and pld $\beta 1-\mathrm{COM}$ plant were inoculated with control solutions (-C) or with pathogens (-T). Control solutions were water for Botrytis cinerea and $10 \mathrm{mM} \mathrm{MgSO}_{4}$ for virulent strain Pst DC3000 and avirulent strain Pst DC3000 (avrRpt2). Leaf samples were collected for lipid profiling $24 \mathrm{~h}$ post inoculation. Values are means of $\pm \operatorname{SE}(n=5)$. Different letters indicate values with significant differences $(P<0.05)$ from each other. 


\section{Supplemental figures}

(a)

(b)
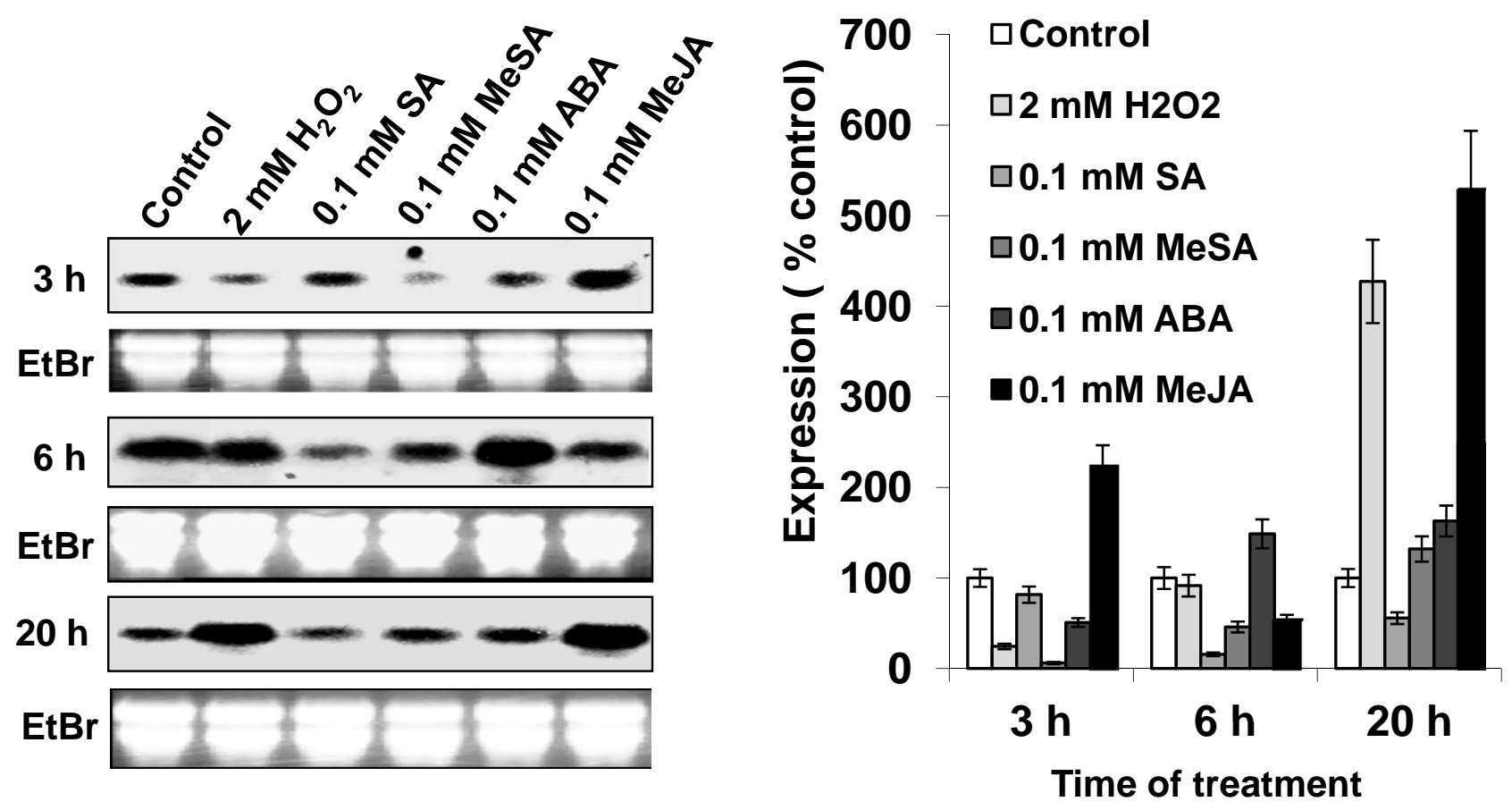

Figure S1. PLD $\beta 1$ Expression Pattern in Arabidopsis Leaves.

(a) Expression of $P L D \beta 1$ in response to various stresses. Arabidopsis Col-0 ecotype (3 week old) leaves were detached and floated on water without (Control) or with indicated chemicals: $2 \mathrm{mM} \mathrm{H}_{2} \mathrm{O}_{2}$, $0.1 \mathrm{mM}$ salicylic acid (SA), $0.1 \mathrm{mM}$ methyl salicylic acid (MeSA), $0.1 \mathrm{mM}$ abscisic acid (ABA), or 0.1 $\mathrm{mM}$ methyl jasmonate (MeJA) in a growth chamber at $22^{\circ} \mathrm{C}$. Leaves were collected at the indicated times for RNA extraction and northern blotting. All sample RNAs from different treatments at different time points were equally loaded as indicated by ethidium bromide-stained 28S RNA. One representative photos from three repeats was shown.

(b) Quantification of $P L D \beta 1$ in response to stresses. Data were average with S.D. made using software to measure band intensity compared with control. 


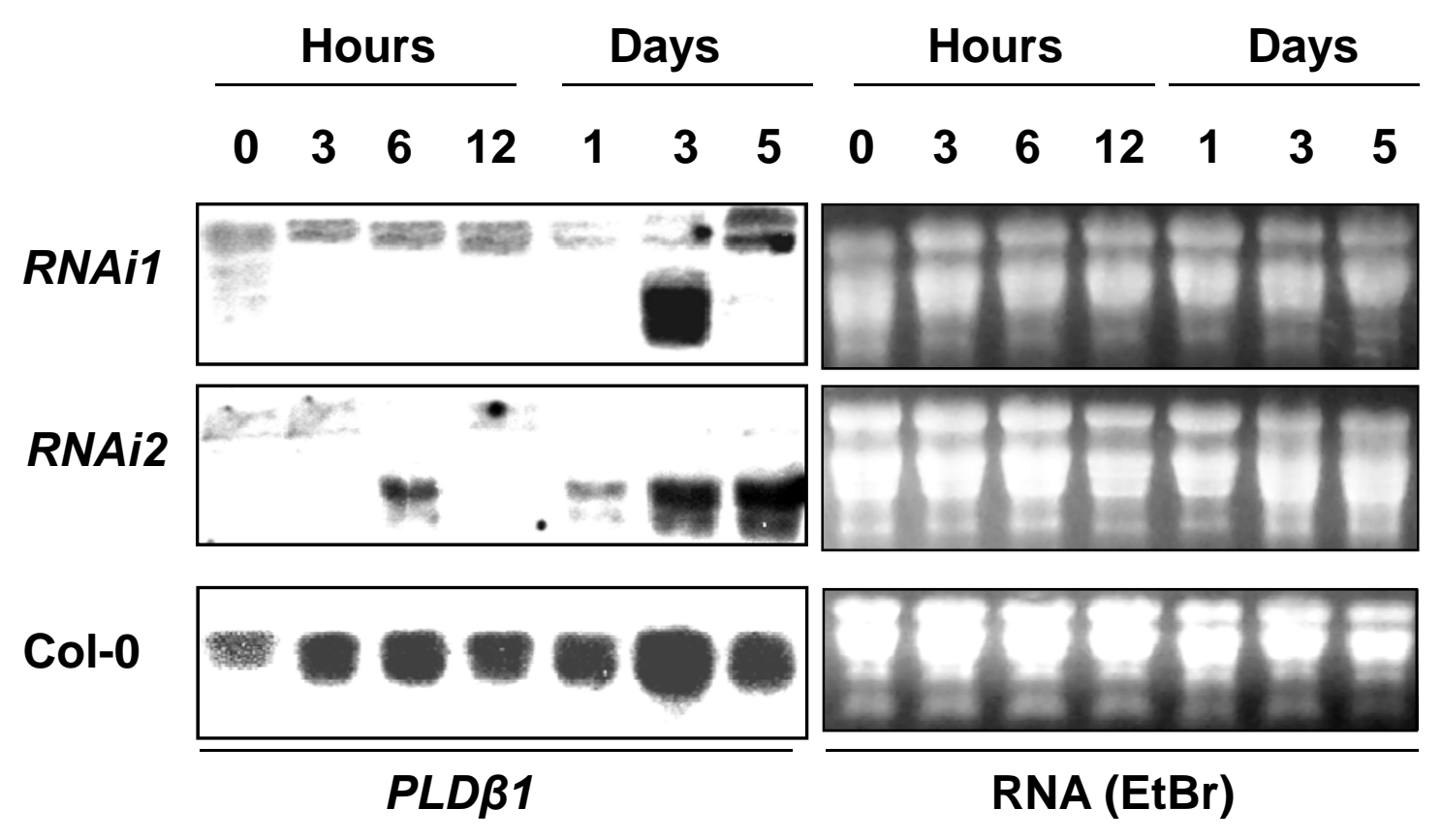

Figure S2. PLD 31 expression induced by Botrytis cinerea infection in Col-0 and PLDß1 Arabidopsis mutants.

Equal amounts of RNAs from leaves were loaded as indicated by ethidium bromide-stained 28S RNA, one representative 28S RNA from three experiments was shown here. 


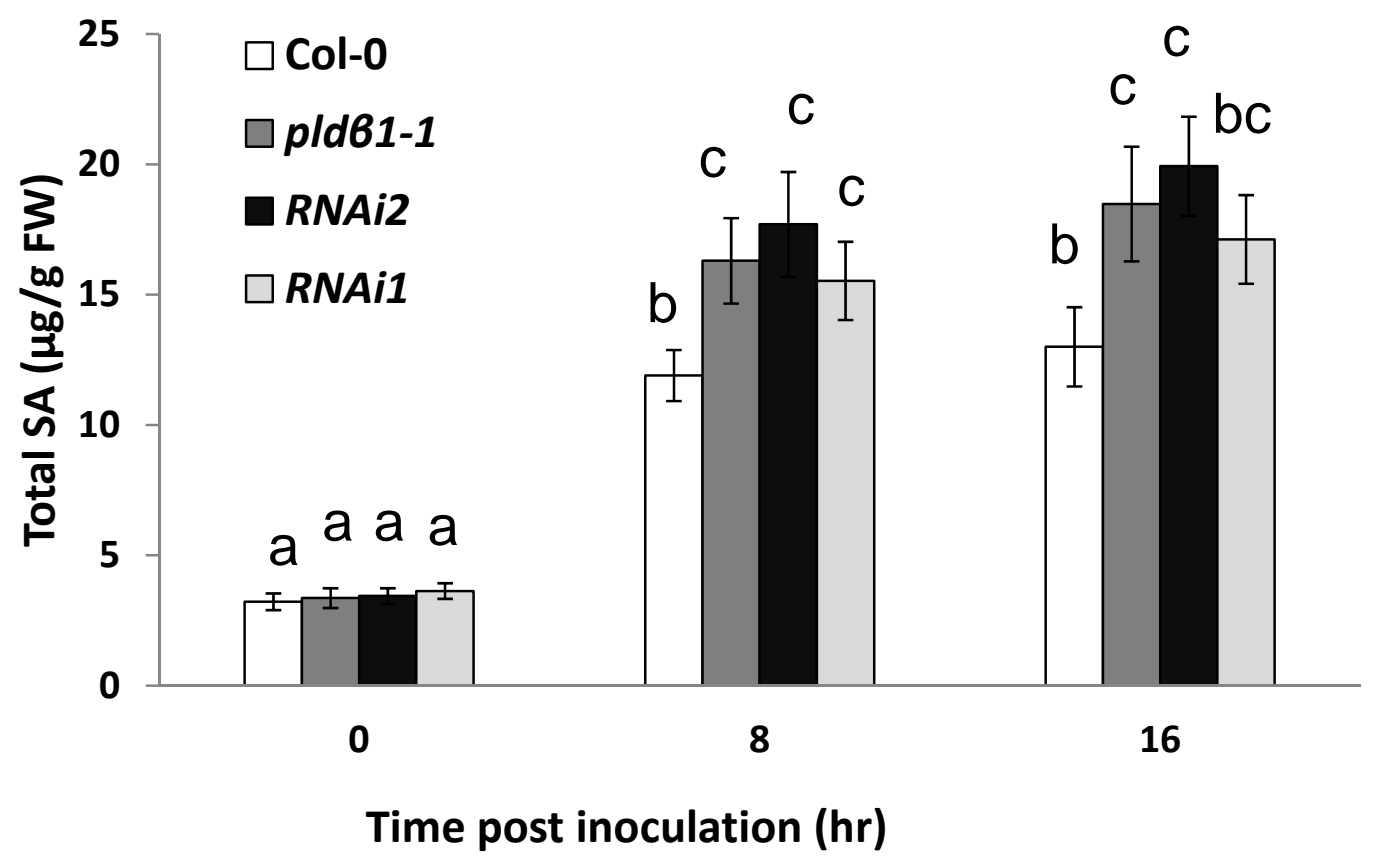

Figure S3. Salicylic acid in pathogen-inoculated PLDß1 Arabidopsis mutants. Samples were harvested after inoculation of Pst DC3000 (avrRpt2) $\left(2 \times 10^{7} \mathrm{cfu} / \mathrm{mL}\right)$. Total SA (free SA + SA Glycosides) in the wild-type , pld $\beta 1-1, R N A i 1, R N A i 2$, and pld $\beta 1$ 1 complementation plants were determined by HPLC. Data are presented as means \pm SD $(\mathrm{n}=3)$. Different letters indicate sample groups with significant differences $(p<0.05)$ from each other. 
(a)
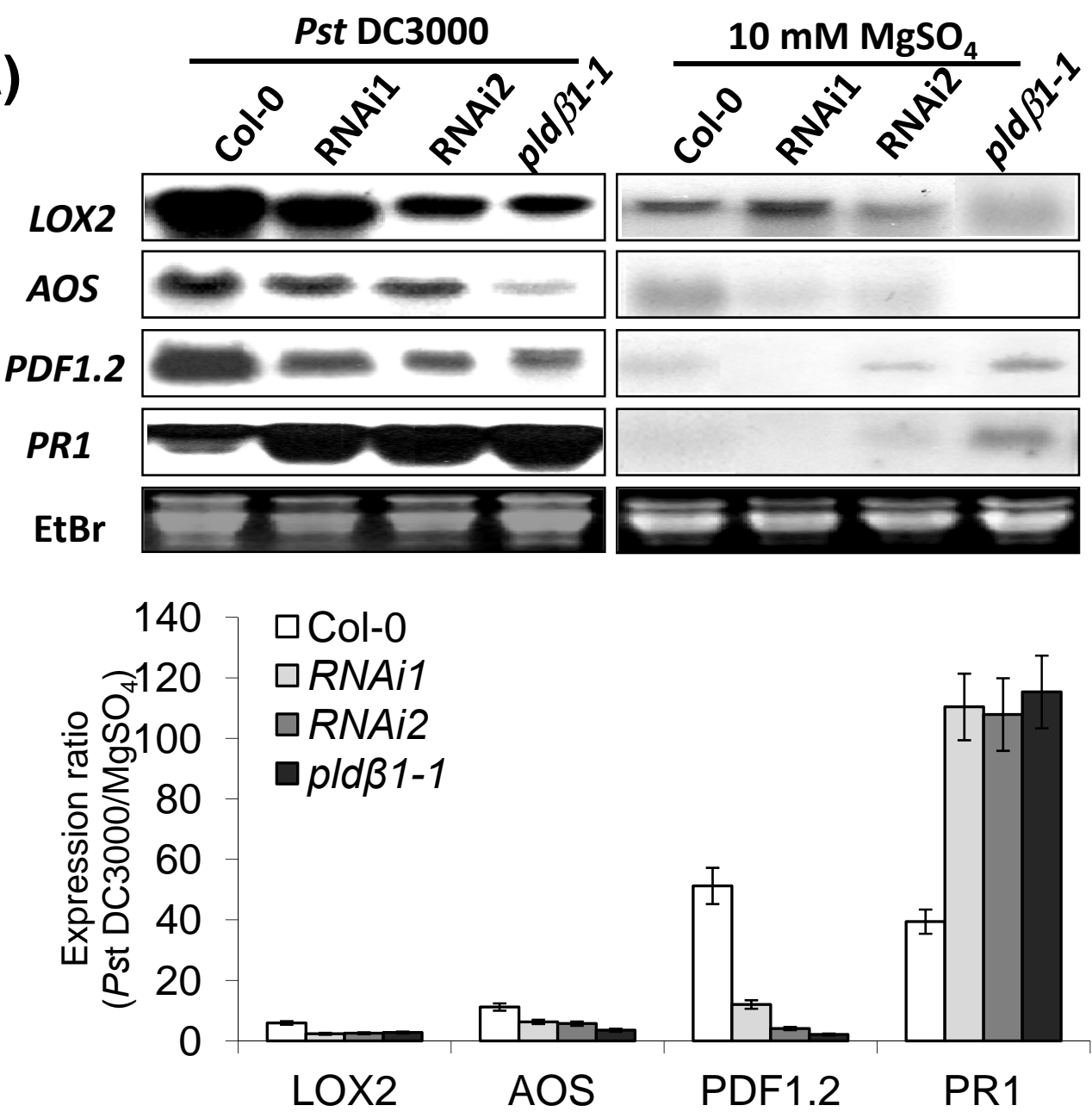

(b)

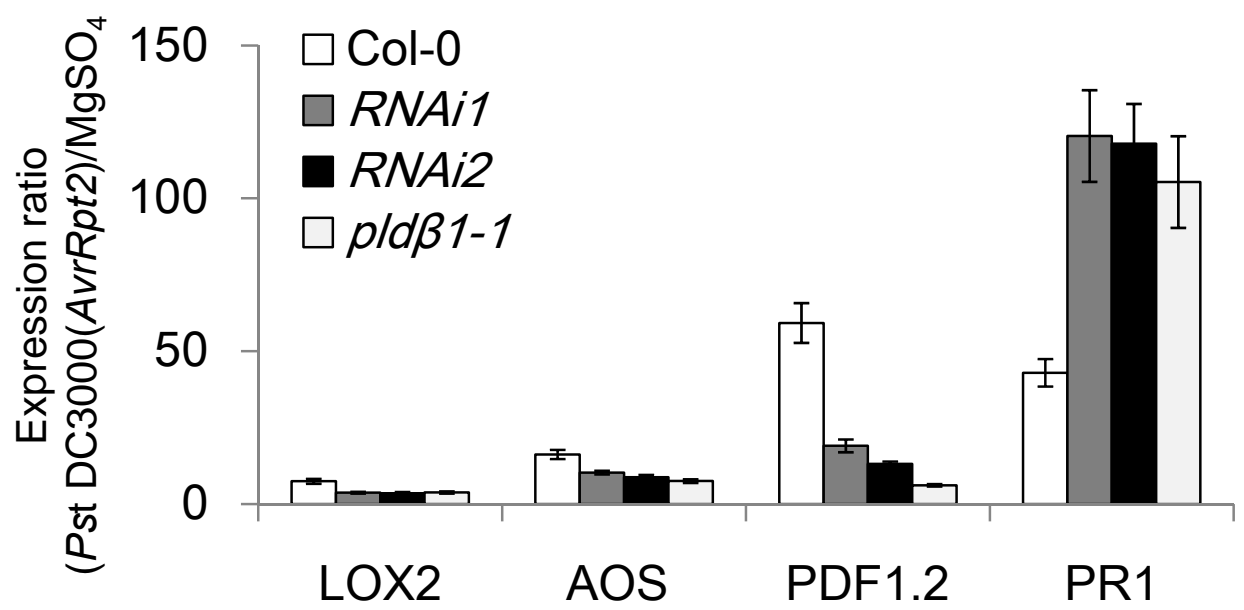

Figure S4. Bacterial infection-induced defense gene expression in Arabidopsis wild-type and pldק1-1.

RNA blotting and quantification of expression levels of defense-related genes in Pst DC3000 (a) and Pst DC3000 (avrRpt2). (b)(2 x $\left.10^{7} \mathrm{cfu} / \mathrm{mL}\right)$ inoculated plants with altered $P L D \beta 1$ expression in Fig. 3C. Equal amounts of RNAs from leaves were loaded as indicated by ethidium bromide-stained $28 \mathrm{~S}$ RNA, one representative 28S RNA from three experiments was shown here. The band intensity was measured by densitometry from three separate experiments. 


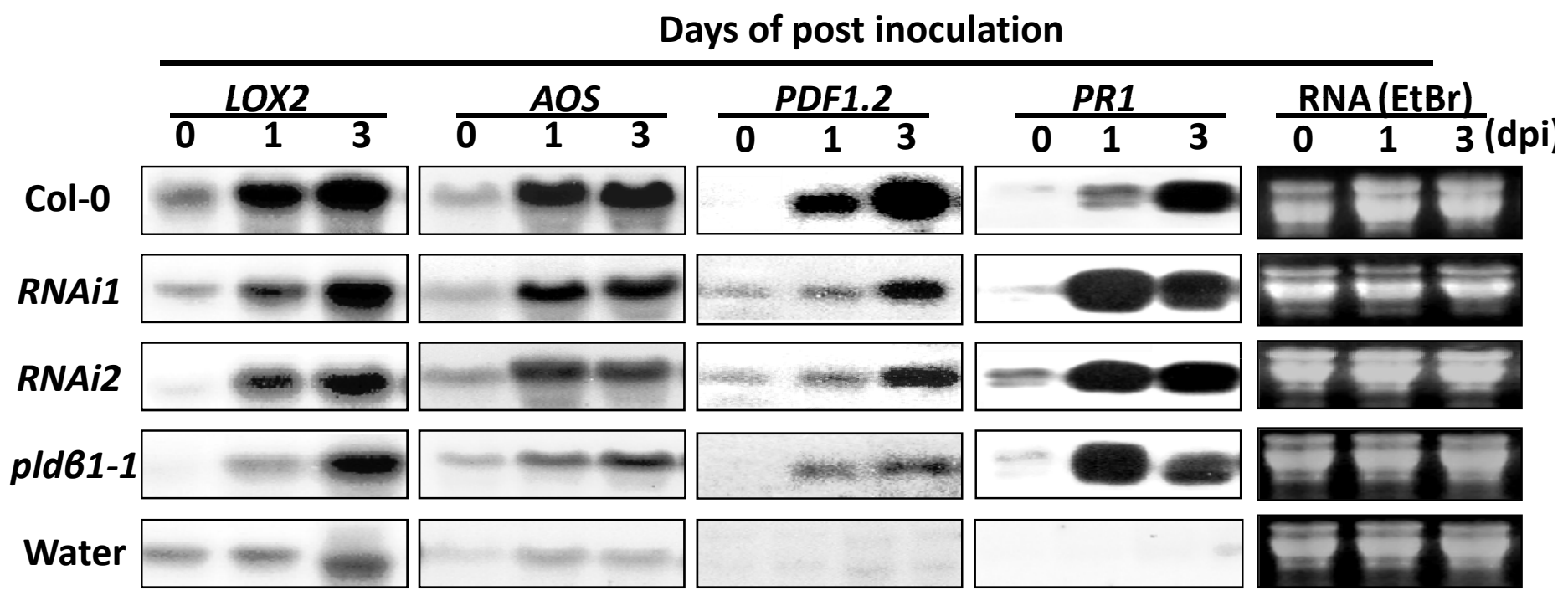

Figure S5. Defense-related gene expression induced by Botrytis cinerea infection in Arabidopsis Col-0 and $P L D \beta 1$ mutants.

Equal amounts of RNAs from leaves were loaded. RNAs from leaf samples were equally loaded as indicated by ethidium bromide-stained 28S RNA, one representative 28S RNA from three experiments was shown here. 


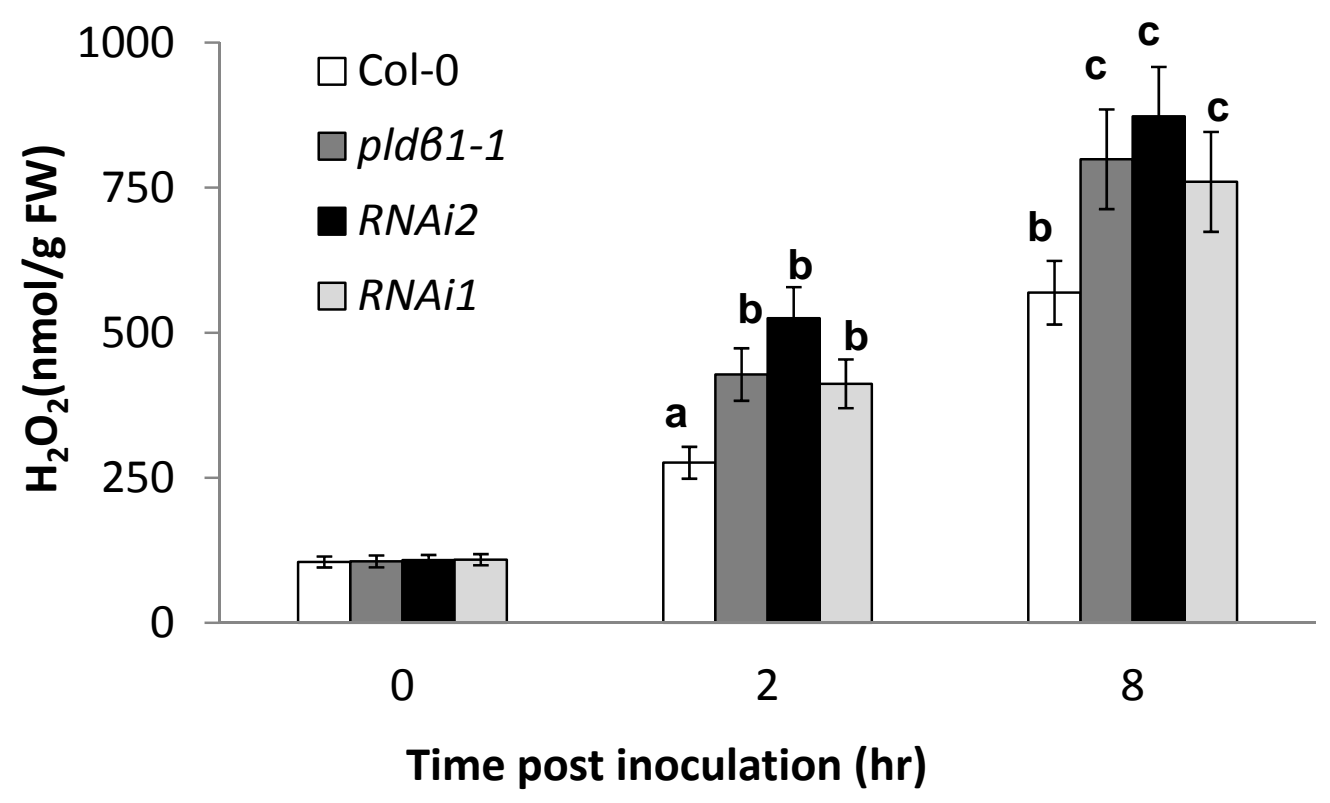

Fig S6. $\mathrm{H}_{2} \mathrm{O}_{2}$ quantification in Pst DC3000 (avrRpt2)-infected Arabidopsis leaves. The wild-type (Col-0), pld $\beta 1-1$, and RNAi2 plants were inoculated with Pst DC3000 (2 x $10^{7}$ $\mathrm{cfu} / \mathrm{ml})$ and leaves were collected at different time post inoculation. Data are presented as means $\pm \mathrm{SD}(\mathrm{n}=5)$. Different letters indicate sample groups with significant differences $(p<0.05)$ from each other. 


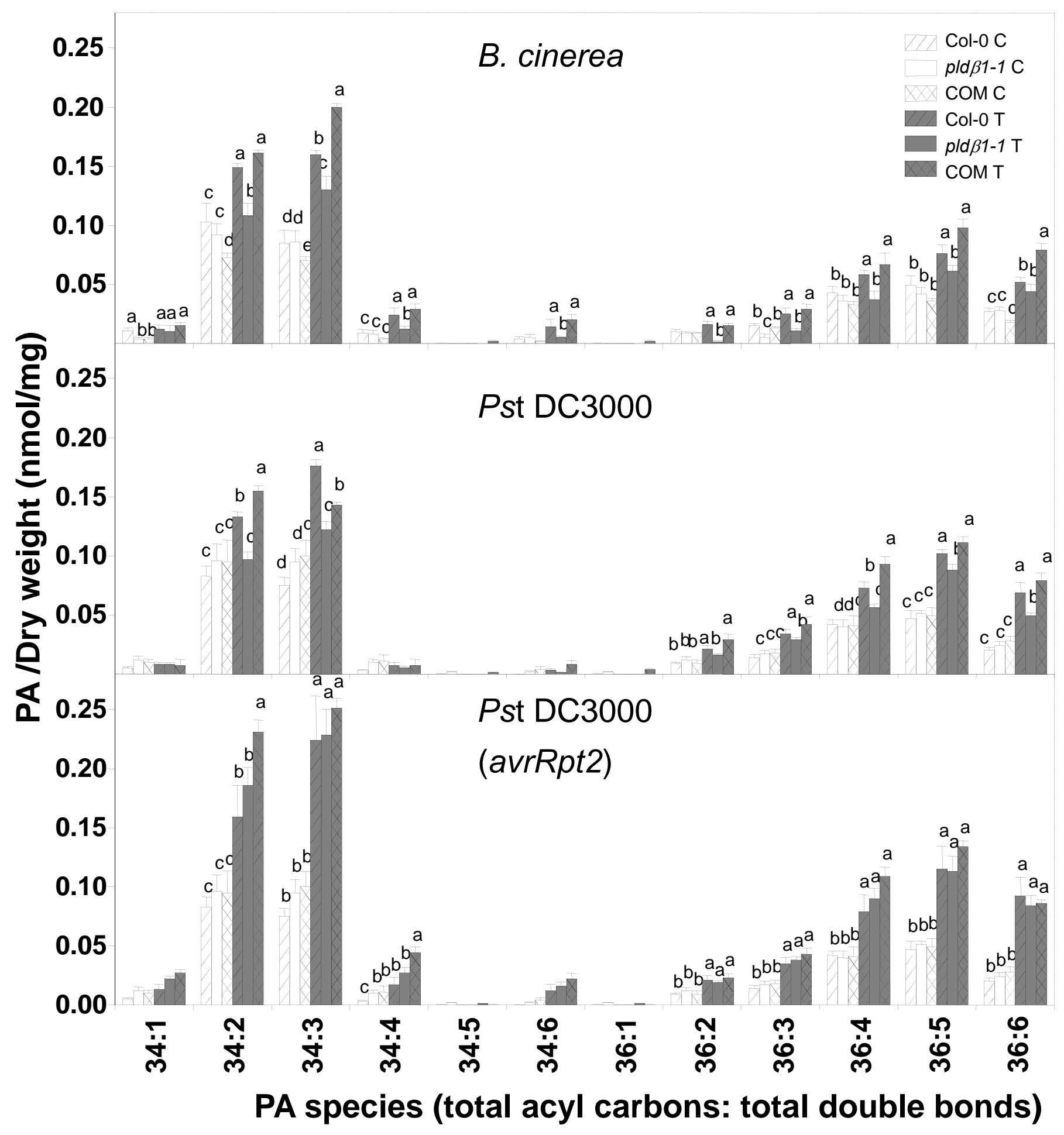

Figure S7. Profiling of PA species from from leaves of Col-0, pldß1-1, and pldß1-COM Arabidopsis plants with and without inoculation of $B$. cinerea, Pst DC3000, or avirulent Pst DC3000 (avrRpt2). Col-0, pld $\beta 1-1$, and pld $\beta 1$ complementation (COM) plant were inoculated with control solutions (-C) or with pathogens (-T). Control solutions were water for Botrytis cinerea and $10 \mathrm{mM} \mathrm{MgSO}_{4}$ for virulent strain Pst DC3000 and avirulent strain Pst DC3000 (avrRpt2). Leaf samples were collected for lipid profiling 24 h post inoculation. Values are means \pm SE $(n=5)$. Different letters indicate sample groups with significant differences $(p<0.05)$ from each other. 
(a)

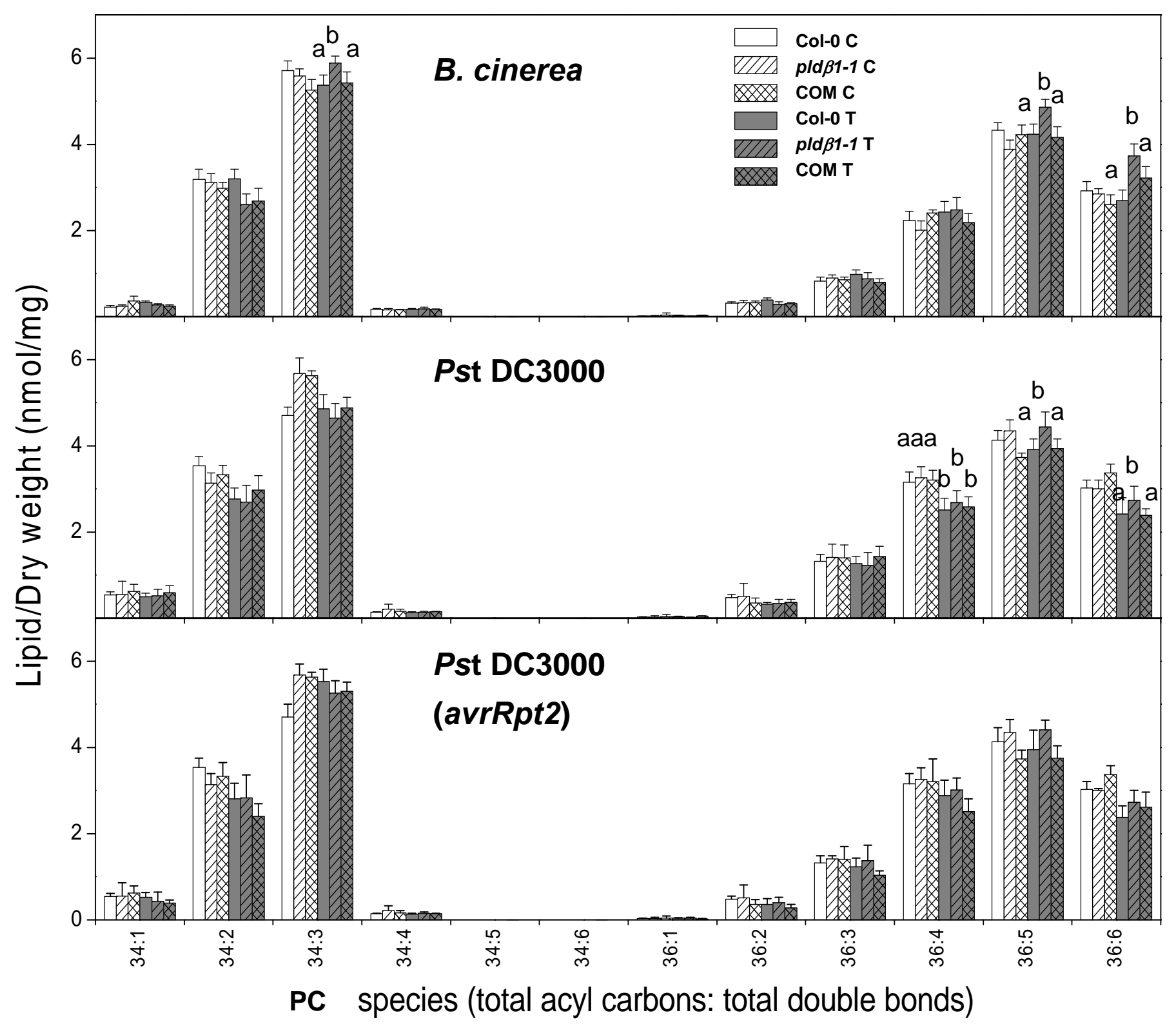


(b)

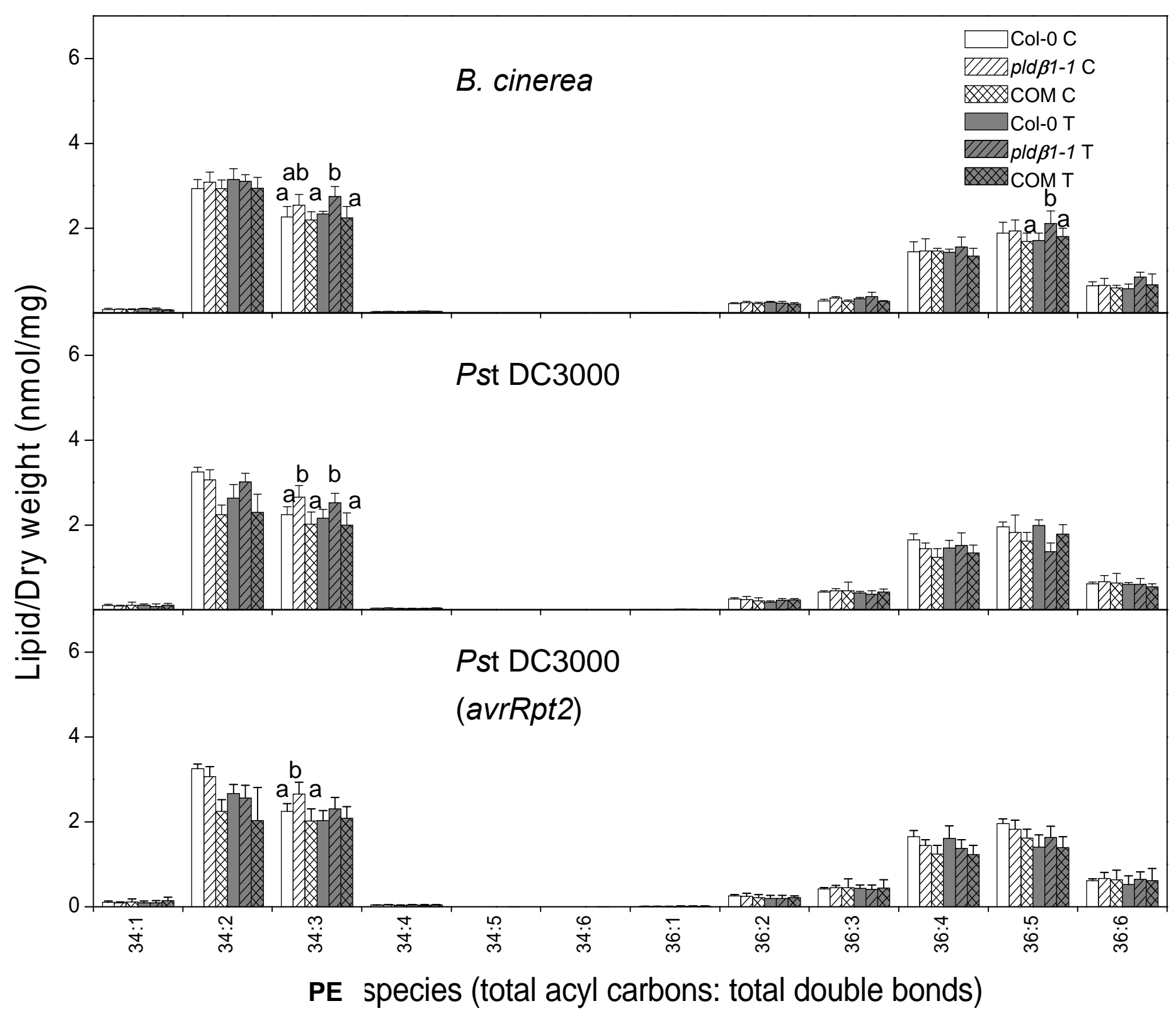

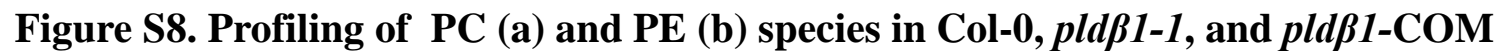
Arabidopsis plants inoculated with control solutions (-C) or with pathogens (-T).

Control solutions were water for Botrytis cinerea spores and $10 \mathrm{mM} \mathrm{MgSO}_{4}$ for virulent strain Pst DC3000 and avirulent strain Pst DC3000 (avrRpt2). Leaf samples were collected for lipid profiling $24 \mathrm{~h}$ post inoculation. Values are means of $\pm \mathrm{SE}(\mathrm{n}=5)$. Different letters indicate sample groups with significant differences $(p<0.05)$ from each other. 
(a)

\section{LysoPC}

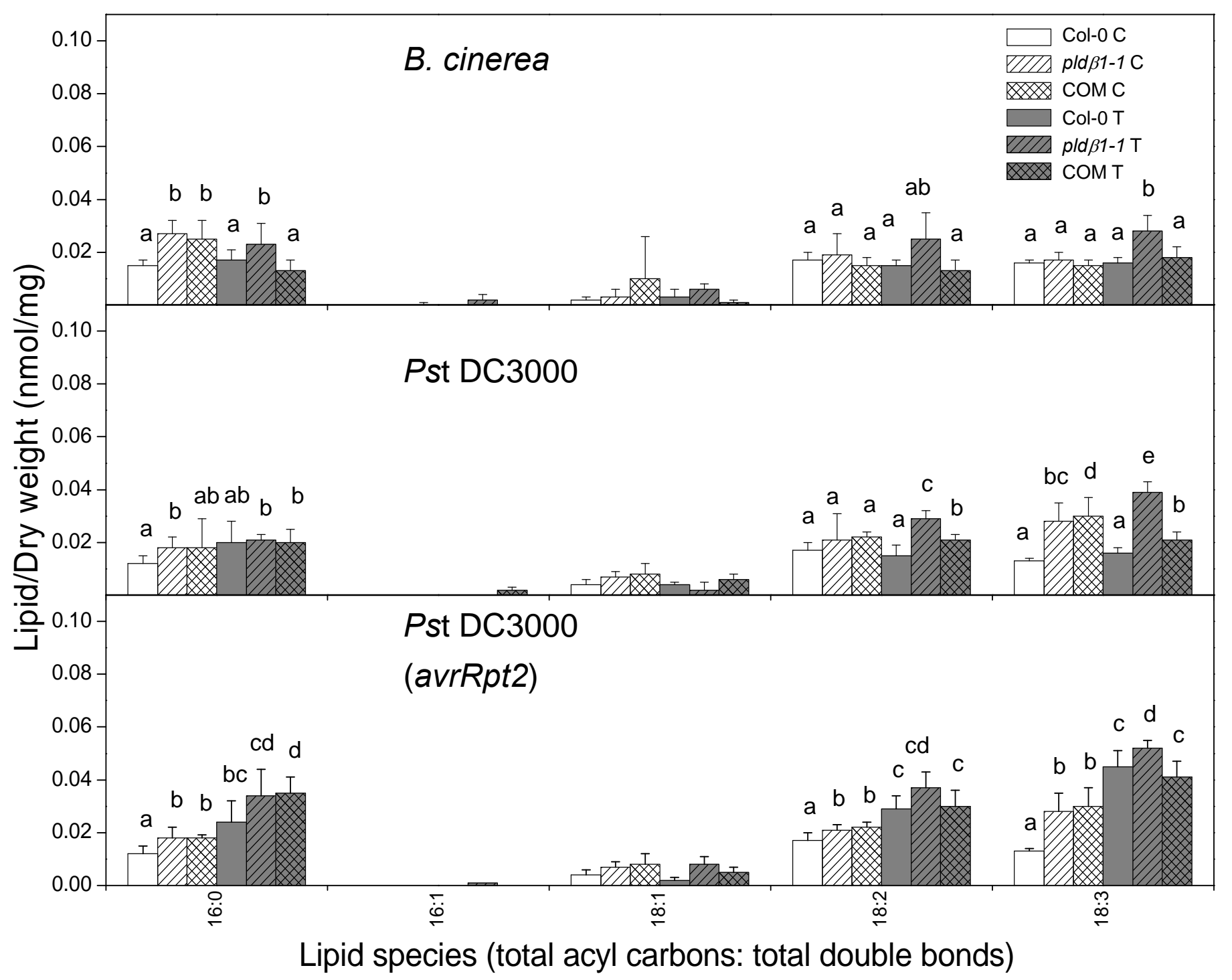

Figure S9(a). Profiling of lysoPC species from leaves of Col-0, pldß1-1, and pldß1-COM Arabidopsis plants with and without inoculation of $B$. cinerea, Pst DC3000, or avirulent Pst DC3000 (avrRpt2).

Col-0, pld $\beta 1-1$, and pld $\beta 1$-COM plant were inoculated with control solutions (-C) or with pathogens (-T). Control solutions were water for Botrytis cinerea and $10 \mathrm{mM} \mathrm{MgSO}_{4}$ for virulent strain Pst DC3000 and avirulent strain Pst DC3000 (avrRpt2). Leaf samples were collected for lipid profiling $24 \mathrm{~h}$ post inoculation. Values are means of $\pm \mathrm{SE}(\mathrm{n}=5)$. Different letters indicate sample groups with significant differences $(\mathrm{P}<0.05)$ from each other. 
(b)

\section{LysoPE}

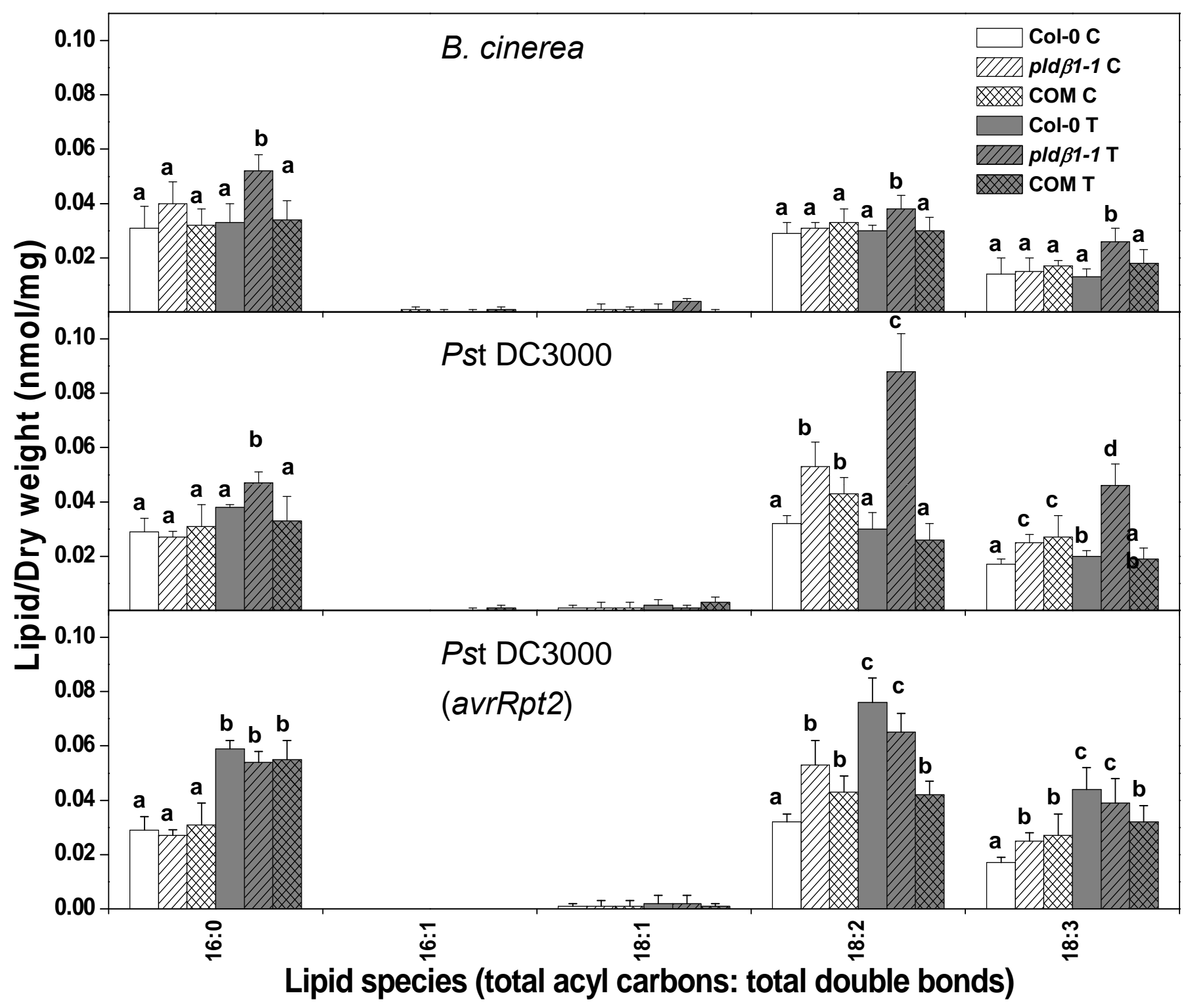

Figure S9(b). Profiling of lysoPE species from leaves of Col-0, pldß1-1, and pldß1-COM plants with and without inoculation of $B$. cinerea, Pst DC3000, or avirulent Pst DC3000 (avrRpt2). Col-0, pld $\beta 1$ 1 , and pld $\beta 1$-COM plant were inoculated with control solutions (-C) or with pathogens (-T). Control solutions were water for Botrytis cinerea and $10 \mathrm{mM} \mathrm{MgSO}_{4}$ for virulent strain Pst DC3000 and avirulent strain Pst DC3000 (avrRpt2). Leaf samples were collected for lipid profiling 24 h post inoculation. Values are means of \pm SE $(n=5)$. Different letters indicate sample groups with significant differences (P $<0.05$ ) from each other. 


\section{(c)}

\section{Lyso PG}

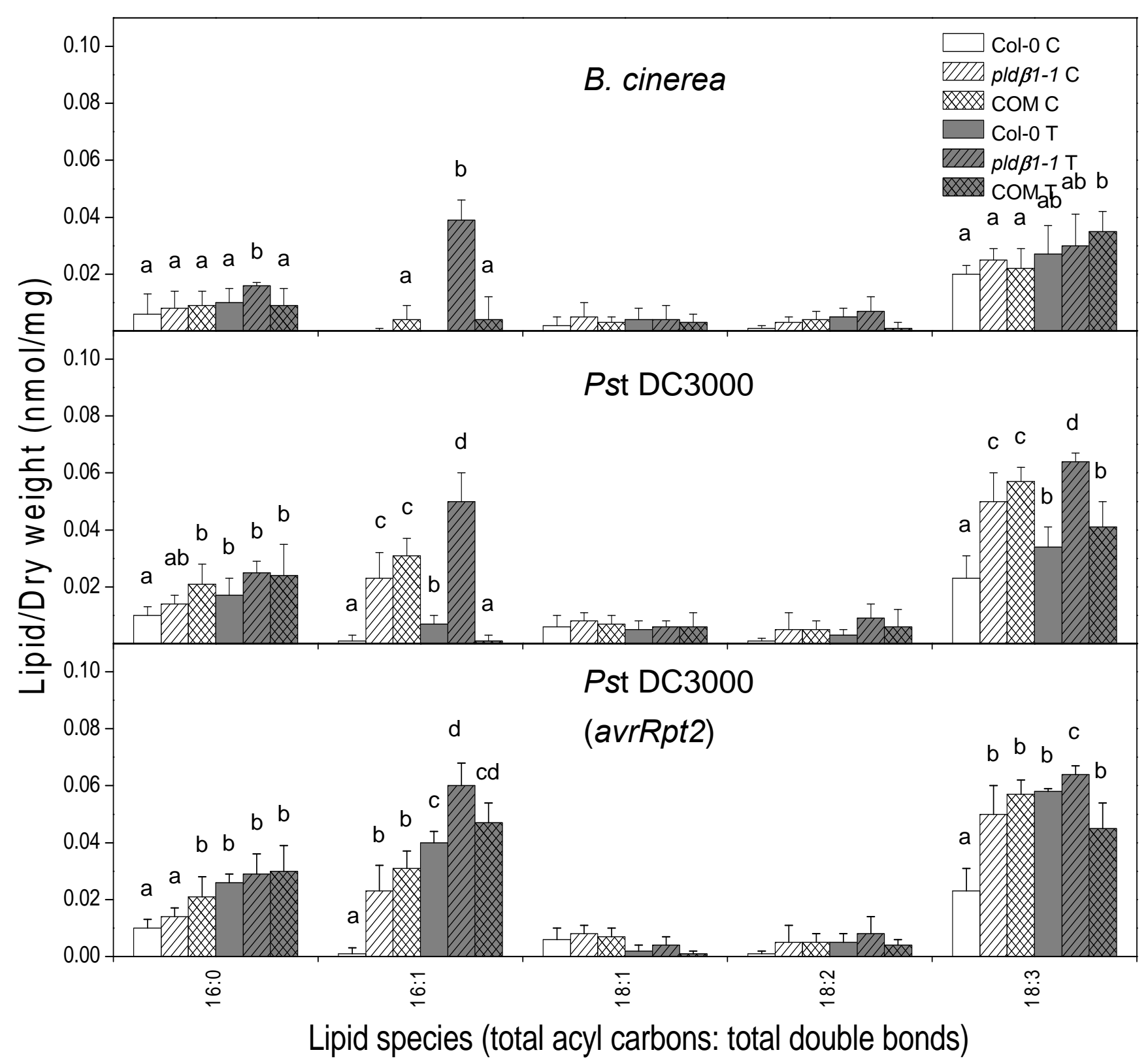

Figure S9C. Profiling of lysoPG species from leaves of Col-0, pldß1-1, and pldß1-COM Arabidopsis plants with and without inoculation of $B$. cinerea, Pst DC3000, or avirulent Pst DC3000 (avrRpt2). Col-0, pld $\beta 1-1$, and pld $\beta 1$-COM plant were inoculated with control solutions (-C) or with pathogens (-T). Control solutions were water for Botrytis cinerea and $10 \mathrm{mM} \mathrm{MgSO}_{4}$ for virulent strain Pst DC3000 and avirulent strain Pst DC3000 (avrRpt2). Leaf samples were collected for lipid profiling $24 \mathrm{~h}$ post inoculation. Values are means of $\pm \mathrm{SE}(\mathrm{n}=5)$. Different letters indicate sample groups with significant differences $(\mathrm{P}<0.05)$ from each other. 